OPEN ACCESS

Edited by:

Roberto Contestabile,

Sapienza University of Rome, Italy

Reviewed by:

Angela Tramonti,

Istituto di Biologia e Patologia Molecolari (IBPM), Consiglio Nazionale

Delle Ricerche (CNR), Italy Riccardo Percudani,

University of Parma, Italy

*Correspondence:

Fabian M. Commichau

fcommic1@gwdg.de

Specialty section:

This article was submitted to Protein Chemistry and Enzymology, a section of the journal Frontiers in Molecular Biosciences

Received: 13 March 2019 Accepted: 18 April 2019

Published: 10 May 2019

Citation:

Richts $B$, Rosenberg $J$ and Commichau FM (2019) A Survey of Pyridoxal 5'-Phosphate-Dependent Proteins in the Gram-Positive Model Bacterium Bacillus subtilis. Front. Mol. Biosci. 6:32. doi: 10.3389/fmolb.2019.00032

\section{A Survey of Pyridoxal 5'-Phosphate-Dependent Proteins in the Gram-Positive Model Bacterium Bacillus subtilis}

\author{
Björn Richts, Jonathan Rosenberg and Fabian M. Commichau* \\ Department of General Microbiology, University of Goettingen, Göttingen, Germany
}

The B6 vitamer pyridoxal 5'-phosphate (PLP) is a co-factor for proteins and enzymes that are involved in diverse cellular processes. Therefore, PLP is essential for organisms from all kingdoms of life. Here we provide an overview about the PLP-dependent proteins from the Gram-positive soil bacterium Bacillus subtilis. Since B. subtilis serves as a model system in basic research and as a production host in industry, knowledge about the PLP-dependent proteins could facilitate engineering the bacteria for biotechnological applications. The survey revealed that the majority of the PLP-dependent proteins are involved in metabolic pathways like amino acid biosynthesis and degradation, biosynthesis of antibacterial compounds, utilization of nucleotides as well as in iron and carbon metabolism. Many PLP-dependent proteins participate in de novo synthesis of the co-factors biotin, folate, heme, and $\mathrm{NAD}^{+}$as well as in cell wall metabolism, tRNA modification, regulation of gene expression, sporulation, and biofilm formation. A surprisingly large group of PLP-dependent proteins (29\%) belong to the group of poorly characterized proteins. This review underpins the need to characterize the PLP-dependent proteins of unknown function to fully understand the "PLP-ome" of $B$. subtilis.

Keywords: vitamin B6, PLP-ome, amino transferase, metabolic engineering, toxicity

\section{INTRODUCTION}

The term "vitamin B6" collectively designates the vitamers pyridoxal (PL), pyridoxine (PN), and pyridoxamine (PM), and the respective phosphate esters pyridoxal 5' -phosphate (PLP), pyridoxine $5^{\prime}$-phosphate (PNP), and pyridoxamine 5'-phosphate (PMP) (György, 1956; Rosenberg, 2012) (Figure 1A). Since vitamin B6 is an essential micronutrient component in the diet of mammals, it is of commercial interest for the pharmaceutical and the food industry (Domke et al., 2005; Fitzpatrick et al., 2007, 2010; Eggersdorfer et al., 2012; Kraemer et al., 2012; Rosenberg et al., 2017; Acevedo-Rocha et al., 2019). As yet, the B6 vitamers are chemically synthesized via different routes (Pauling and Weimann, 1996; Kleemann et al., 2008; Eggersdorfer et al., 2012). Since chemical synthesis requires the usage of expensive and/or toxic chemicals, the shift from chemical synthesis to sustainable fermentation technologies using microorganisms is of great interest (Rosenberg et al., 2017; Acevedo-Rocha et al., 2019). So far, the microbial vitamin B6 production processes could not replace chemical production processes (Commichau et al., 2014, 2015; Rosenberg et al., 2017, 2018; Acevedo-Rocha et al., 2019). 
PLP is a co-factor for many proteins and enzymes (Jansonius, 1998; Christen and Mehta, 2001; Eliot and Kirsch, 2004; Phillips, 2015). About $1.5 \%$ of the genes of free-living prokaryotes encode PLP-dependent proteins and over 160 enzymes with different catalytic activities require vitamin B6 as a co-factor (about $4 \%$ of all described catalytic activities) (Percudani and Peracchi, 2003, 2009). Certainly, novel PLP-dependent proteins and enzymes will be identified and characterized in the future because the number of sequenced genomes is increasing (https://www.ncbi. nlm.nih.gov/genome/browse/\#!/overview/). The majority of the PLP-dependent enzymes are involved in amino acid metabolism (John, 1995; Eliot and Kirsch, 2004). Some enzymes catalyzing decarboxylation and racemization reactions, cleavage of $C_{a^{-}}$ $C_{b}$ bonds, $\alpha$-elimination and replacement as well as $\beta$ - and $\gamma$-elimination or replacement reactions also require PLP as a co-factor. Moreover, PMP and PM serves as co-factors for enzymes of deoxysugar and amino acid biosynthetic pathways, respectively (Burns et al., 1996; Mehta and Christen, 2000; Yoshikane et al., 2006; Romo and Liu, 2011). PLP also modulates the activity of DNA-binding transcription factors in eukaryotes and prokaryotes (Oka et al., 2001; Belitsky, 2004a, 2014; Huq et al., 2007; El Qaidi et al., 2013; Tramonti et al., 2015, 2017; Suvorova and Rodionov, 2016). Moreover, vitamin $\mathrm{B} 6$ is implicated in oxidative stress responses (Bilski et al., 2000; Mooney et al., 2009; Mooney and Hellmann, 2010; Vanderschuren et al., 2013; Moccand et al., 2014). Thus, vitamin B6 fulfills a variety of vital functions in different cellular processes (Parra et al., 2018).

\section{DE NOVO SYNTHESIS OF VITAMIN B6}

Two pathways for de novo PLP synthesis are currently known (Figure 1B) (Mittenhuber, 2001; Tanaka et al., 2005; Fitzpatrick et al., 2007, 2010; Rosenberg et al., 2017). The deoxyxylulose5-phosphate (DXP)-dependent vitamin B6 biosynthesis pathway was identified in the Gram-negative model bacterium Escherichia coli and consists of two branches and seven enzymatic steps. The first three enzymes Epd, PdxB, and SerC of the longer branch convert a pentose phosphate pathway intermediate to 4-phosphohydroxy-L-threonine (4HTP) (Figure 1B) (Zhao et al., 1995; Drewke et al., 1996; Boschi-Muller et al., 1997; Tazoe et al., 2006; Rudolph et al., 2010). Next, PdxA converts 4HTP to 2-amino-3-oxo-4-(phosphohydroxy)butyric acid, which undergoes spontaneous decarboxylation to 3phosphohydroxy-1-aminoacetone (Cane et al., 1998; Laber et al., 1999; Sivaraman et al., 2003). The PNP synthase PdxJ produces the B6 vitamer PNP from 3-phosphohydroxy-1-aminoacetone and DXP, of which the latter substrate is generated by the DXP synthase Dxs from glyceraldehyde 3-phosphate and pyruvate in the short branch of the DXP-dependent vitamin B6 pathway (Figure 1B) (Takiff et al., 1992; Sprenger et al., 1997; Cane et al., 1999; Laber et al., 1999). The PNP oxidase PdxH catalyzes the final step yielding in the biologically most-relevant B6 vitamer PLP (Zhao and Winkler, 1995). The DXP-dependent vitamin B6 pathway is present in $\alpha$ - and $\gamma$-proteobacteria (Mittenhuber, 2001; Tanaka et al., 2005). Recently, it has been shown that bacteria possess promiscuous enzymes that may feed into the DXP-dependent pathway and bypass a block in pyridoxal- $5^{\prime}$ phosphate synthesis (Figure 1B) (Kim J. et al., 2010; Kim and Copley, 2012; Smirnov et al., 2012; Oberhardt et al., 2016; Thiaville et al., 2016; Zhang et al., 2016; Rosenberg et al., 2018). The hybrid pathways consisting of enzymes of native and nonnative vitamin $\mathrm{B} 6$ pathways and of promiscuous enzymes may be improved by metabolic engineering to enhance production of B6 vitamers (Rosenberg and Commichau, 2019).

The DXP-independent vitamin B6 biosynthetic pathway involves only the PdxST enzyme complex (Ehrenshaft and Daub, 2001; Belitsky, 2004b; Burns et al., 2005; Raschle et al., 2005; Strohmeier et al., 2006). PdxT is a glutaminase that hydrolyses glutamine into glutamate and ammonium, of which the latter serves as a substrate to the PLP synthase PdxS (Belitsky, 2004b). The PdxS subunit generates PLP from ammonium together with either ribulose 5-phosphate or ribose 5-phosphate and with either G3P or dihydroxyacetone phosphate (Figure 1B). Many organisms possess a salvage pathway for the interconversion of the B6 vitamers (Figure 1B) (Fitzpatrick et al., 2007; di Salvo et al., 2011). For instance, specific B6-vitamer kinases can phosphorylate PN, PM and PL into their respective phosphate esters (White and Dempsey, 1970; Yang et al., 1996, 1998; di Salvo et al., 2004; Park et al., 2004). Those organisms carrying only salvage pathways have to take up B6 vitamers. So far, only few vitamin B6 transporters have been in described in eukaryotes (Stolz and Vielreicher, 2003; Szydlowski et al., 2013). The accumulation of PLP to toxic levels can be prevented by dephosphorylation and export of PL. Indeed, bacteria like $E$. coli and Sinorhizobium meliloti synthesize a phosphatase for dephosphorylation of PNP and PLP (Tazoe et al., 2005; Nagahashi et al., 2008; Sugimoto et al., 2017).

\section{VITAMIN B6 METABOLISM IN BACILLUS SUBTILIS}

The Gram-positive model bacterium Bacillus subtilis relies on the PdxST enzyme complex to synthesize the B6 vitamer PLP (Pflug and Lingens, 1978; Sakai et al., 2002b; Belitsky, 2004b; Burns et al., 2005). The B. subtilis PdxST enzyme complex has been biochemically and structurally studied (Raschle et al., 2005; Zhu et al., 2005; Strohmeier et al., 2006; Wallner et al., 2009; Smith et al., 2015). In many Gram-positive bacteria, the expression of the $p d x S T$ genes and the genes encoding kinases that phosphorylate the $\mathrm{B} 6$ vitamers $\mathrm{PM}, \mathrm{PN}$, and $\mathrm{PL}$, are regulated by MocR-like DNA-binding transcription factors (Jochmann et al., 2011; El Qaidi et al., 2013; Belitsky, 2014; Liao et al., 2015; Tramonti et al., 2015; Suvorova and Rodionov, 2016). In B. subtilis the $p d x S T$ genes are not subject to transcriptional regulation (Nicolas et al., 2012).

B. subtilis must possess an uptake system and a kinase for the B6 vitamer PL because exogenously supplied PL relieves PLP auxotrophy of a pdxST mutant (Belitsky, 2004b; Commichau et al., 2014). The uptake system and the kinase are not specific for PL because the overexpression of the E. coli $p d x H$ $\mathrm{PN}(\mathrm{P})$ oxidase gene in a $B$. subtilis $p d x S T$ mutant enabled the 
A

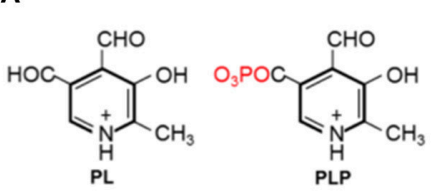<smiles>Cc1[nH]cc(O)c1CO</smiles><smiles></smiles><smiles></smiles><smiles></smiles>

\section{B}

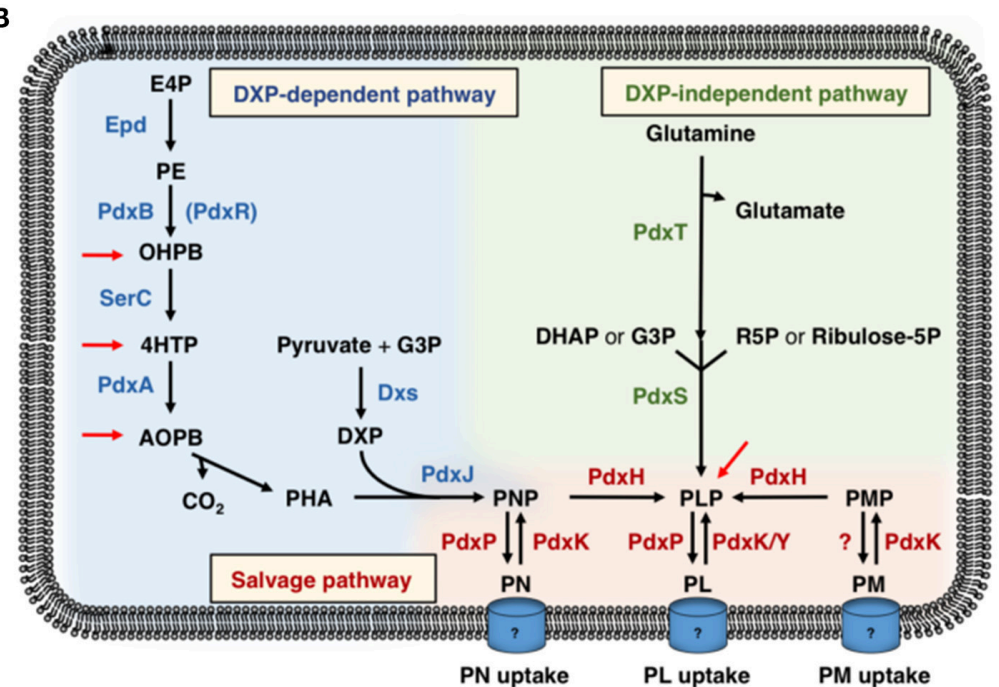

FIGURE 1 | (A) The B6 vitamers: pyridoxal (PL), pyridoxal 5'-phosphate (PLP), pyridoxine (PN), pyridoxine 5'-phosphate (PNP), pyridoxamine (PM), and pyridoxamine 5'-phosphate (PMP). (B) The deoxyxylulose 5-phosphate (DXP)-dependent and DXP-independent vitamin B6 biosynthetic routes and the salvage pathway for the interconversion of the B6 vitamers. Epd, erythrose 4-phosphate dehydrogenase; PdxB (PdxR), 4-phosphoerythronate dehydrogenase; SerC, 3-phosphoserine aminotransferase; PdxA, 4-phosphohydroxy-L-threonine dehydrogenase; PdxJ, PNP synthase; Dxs, 1-deoxyxylulose 5-phosphate synthase; PdxH, PNP oxidase; PdxS (PLP synthase subunit), and PdxT (glutaminase subunit) form the PLP synthase complex; PdxK, PL kinase present in B. subtilis and E. coli; PdxY, PL kinase present in E. coli. PdxK from B. subtilis has PN, PL, and PM kinase activity (see text). E4P, erythrose 4-phosphate; 4PE, 4-phosphoerythronate; OHPB, 2-oxo-3-hydroxy-4-phosphobutanoate; 4HTP, 4-hydroxy-threonine; AOPB, 2-amino-3-oxo-4-(phosphohydroxyl)-butyrate; PHA, 3-phosphohydroxy-1-aminoacetone; DXP, deoxyxylulose-5-phosphate; G3P, glyceraldehyde-3-phosphate; DHAP, dihydroxyacetonephosphate; R5P, Ribose-5-phosphate. Red arrows indicate the steps where promiscuous enzymes may feed into the DXP-dependent and DXP-independent vitamin B6 biosynthetic pathways (Kim J. et al., 2010; Oberhardt et al., 2016; Thiaville et al., 2016; Rosenberg et al., 2018).

bacteria to synthesize PLP from exogenous PN (Commichau et al., 2014). While the PL and PN uptake system remains to be identified in $B$. subtilis, the kinase phosphorylating the $\mathrm{B} 6$ vitamers $\mathrm{PL}, \mathrm{PM}$, and $\mathrm{PN}$ is known (Park et al., 2004; Newman et al., 2006a,b). It is interesting to note that the B. subtilis PL kinase $\mathrm{PdxK}$ is phylogenetically related to HMPP ribokinases converting 4-amino-5-hydroxymethyl2-methylpyrimidine (HMP) to 4-amino-5-hydroxymethyl-2methylpyrimidine phosphate (HMPP) and HMPP to HMPP phosphate, a precursor of thiamine biosynthesis (Mizote et al., 1999; Newman et al., 2006b). In the future, it will be interesting to elucidate whether exogenously supplied PL controls the activity of the PdxST enzyme complex in B. subtilis to prevent the accumulation of PLP to toxic levels (see below).

In contrast to the enzymes of the DXP-dependent vitamin B6 pathway from E. coli, the PdxST enzyme complex from B. subtilis is rather slow (Rosenberg et al., 2017). Therefore, a heterologous DXP-dependent vitamin B6 pathway has been introduced into $B$. subtilis for producing the $\mathrm{B} 6$ vitamer $\mathrm{PN}$ (Commichau et al., 2014, 2015). The fact that the engineered $B$. subtilis strains synthesized significant amounts of $\mathrm{PN}$, which was detectable in the culture supernatant, suggests that the bacteria might possess a PNP phosphatase and an export system for PN. Recently, the PLP phosphatase YbhA has been identified in E. coli (Sugimoto et al., 2017). YbhA shows about 31\% overall sequence identity with the YitU protein from B. subtilis. Even though it has been shown that YitU is a HAD phosphatase having a minor activity in dephosphorylating the riboflavin precursor 5-amino-6-ribitylamino-2,4(1H,3H)-pyrimidinedione $5^{\prime}$-phosphate (Sarge et al., 2015), it will be interesting to test whether the protein may act as a PN/PLP phosphatase.

\section{TOXICITY OF VITAMIN B6 AND PATHWAY INTERMEDIATES}

PLP can be toxic for the cell because the reactive $4^{\prime}$-aldehyde moiety of the B6 vitamer forms covalent adducts with other compounds and PLP-independent proteins containing thiol or amino groups. For instance, PLP was shown to inhibit enzymes that are involved in DNA metabolism and in central carbon metabolism in eukaryotes (Mizushina et al., 2003; Vermeersch et al., 2004; Lee et al., 2005). Moreover, the modification of the $E$. coli initiation factor 3 , the adenylsuccinate synthetase and the PL kinase by PLP results in activity loss (Ohsawa and Gualerzi, 1981; Dong and Fromm, 1990; Ghatge et al., 2012). Recently, it has been shown that the addition of vitamin B6 to the E. coli wild type strain BW25113 and an E. coli mutant strain lacking the ZipA cell division protein affects multiple metabolic pathways, which are involved in amino acid biosynthesis (Vega and Margolin, 2017). Thus, excess of PLP affects different cellular processes. PLP is also prone to damage either due to side reactions that are catalyzed by promiscuous enzymes or due to spontaneous chemical reactions (Linster et al., 2013). In fact, the B6 vitamers PLP and PMP were identified as members of the 30 most damage-prone metabolites (Lerma-Ortiz et al., 2016). However, given the fact that PLP is 
required for optimal growth in little amounts, the essential cofactor can be synthesized at a minimal necessary rate (Hartl et al., 2017). The low requirement of PLP and its low cellular concentration prevent perturbation of other essential processes in the cell.

In the past years, several attempts have been made to engineer bacteria for the overproduction of the $\mathrm{B} 6$ vitamers PL and PN (Rosenberg et al., 2017). In contrast to PL(P), $\mathrm{PN}(\mathrm{P})$ is less toxic for living cells (see above; Commichau et al., 2014). Therefore, the DXP-dependent seems to be a promising pathway for engineering bacteria for vitamin B6 overproduction. However, it has also been shown that intermediates of the DXP-dependent pathway can be highly toxic for bacteria. For instance, the erythrose-4-phosphate dehydrogenase Epd generates the DXP-dependent vitamin B6 pathway intermediate 4-phosphoerythronate (4PE), which is required in low amounts for PLP biosynthesis, is toxic for the cells when overproduced (Sachla and Helmann, 2019). Eukaryotic cells do have a phosphatase that hydrolyzes and detoxifies 4PE that is also mistakenly generated by the glycolytic enzyme glyceraldehyde3-phosphate dehydrogenase (Beaudoin and Hanson, 2016; Collard et al., 2016). 4PE inihibits the 6-phosphogluconate dehydrogenase from the pentosephosphate pathway (Collard et al., 2016). Recently, it has been demonstrated that $4 \mathrm{PE}$ also inhibits the B. subtilis 6-phosphogluconate dehydrogenase GndA (Sachla and Helmann, 2019). In this organism, 4PE is detoxified by the GTPase CpgA, which is a checkpoint protein known to be involved in ribosome assembly (Campbell et al., 2005). It will be interesting to assess whether $4 \mathrm{PE}$ also inhibits the 6-phosphogluconate dehydrogenase in E. coli because the bacterium does not possess a CpgA homolog. However, the accumulation of 4PE to toxic levels does not seem to be problematic in $E$. coli because $4 \mathrm{PE}$ can be produced in only small amounts that are sufficient for de novo synthesis of PLP. The intermediate 4HTP from the DXP-dependent vitamin B6 pathway is also inhibits bacterial growth. 4HTP interferes with biosynthesis of threonine and isoleucine in E. coli and B. subtilis (Drewke et al., 1993; Farrington et al., 1993; Commichau et al., 2014, 2015; Rosenberg et al., 2016). The toxicity of the pathway intermediates may explain why it is difficult to engineer bacteria that stably express the genes of the DXP-dependent vitamin B6 pathway (Commichau et al., 2014). The understanding of the metabolite toxicity is crucial for the rational design and engineering of bacteria overproducing PN at commercially attractive levels. Moreover, the knowledge about the functions of target proteins of PLP is very important to understand how the B6 vitamer affects cellular metabolism upon overproduction.

\section{PLP-DEPENDENT PROTEINS AND ENZYMES INVOLVED IN VITAMIN B6 METABOLISM IN BACILLUS SUBTILIS}

To identify the B. subtilis proteins and enzymes that require PLP for activity and are involved in vitamin B6 metabolism, we compared the Enzyme Commission (E.C.) numbers of the proteins from the B. subtilis 168 laboratory strain found in the
SubtiWiki database (http://subtiwiki.uni-goettingen.de/v3/) (Zhu and Stülke, 2017) with the E.C. numbers that are deposited in the B6 database (Table 1) (http://bioinformatics.unipr.it/cgi-bin/ bioinformatics/B6db/home.pl) (Percudani and Peracchi, 2009). We also describe proteins from the SubtiWiki database that are specific for $B$. subtilis and are therefore not present in the B6 database. Publications describing proteins involved in vitamin B6 metabolism in B. subtilis were also added to the Table. A recent mass spectrometry approach in combination with modified pyridoxal analogs identified proteins in the Grampositive pathogen Staphylococcus aureus that probably depend on the B6 vitamer PLP (Hoegl et al., 2018). The study confirmed the binding of PLP to proteins of known and unknown function and identified 4 additional PLP-binding proteins ( HemH, HemQ, YtoP, and YwlG) (see below). In total we ended up with 65 PLP-dependent proteins in B. subtilis, of which 61 proteins are bona fide PLP-dependent proteins. The PLP-dependency of four proteins remains to be experimentally validated. Table 1 also contains the PDB identifiers of structures that are available in the PDB database for the B. subtilis proteins. In case the structural information was not available, we have added the PDB identifiers from PLP-dependent homologs showing more than $27 \%$ overall sequence identity. We have also included information about the physiological functions of the proteins and their paralogs, the transcription factors that are involved in synthesis of the proteins and information about the sequence similarities with other proteins from the UniProt database (https://www.uniprot. org). The list of proteins involved in vitamin B6 metabolism in $B$. subtilis will certainly be extended in the future because PLPdependent enzymes are ubiquitous and evolutionary diverse, making their classification based on sequence homology difficult.

\section{FUNCTIONAL ASSIGNMENT OF KNOWN PLP-DEPENDENT PROTEINS IN B. SUBTILIS}

Most of the proteins that require PLP in B. subtilis are metabolic enzymes, of which the majority is involved in anabolism and catabolism of proteinogenic and non-proteinogenic amino acids (Table 1; Figure 2). The enzymes can be assigned to known protein families of PLP-dependent enzymes and for most of them it has been shown that they are indeed active in amino acid metabolism (Mehta et al., 1993; Mehta and Christen, 2000) (Table 1). B. subtilis also possesses a PLPdependent 2-amino-3-ketobutyrate $\mathrm{CoA}$ ligase (Kbl), which could be involved in threonine utilization together with the Lthreonine dehydrogenase Tdh (Schmidt et al., 2001; Reitzer, 2005). Both enzymes are encoded in the bicistronic $t d h-k b l$ operon (Nicolas et al., 2012). The regulation of the $t d h$ and $k b l$ genes and the catalytic activities of the Tdh and Kbl enzymes remain to be studied. Two PLP-dependent enzymes BacF and NtdA are involved in the synthesis of bacilysin and kanosamine in B. subtilis. Bacilysin is a non-ribosomally synthesized peptide that is active against various bacteria and some fungi (Inaoka et al., 2003, 2009; Karatas et al., 2003; Köroglu et al., 2011). Kanosamine is an antibiotic, which is produced by Bacillus 


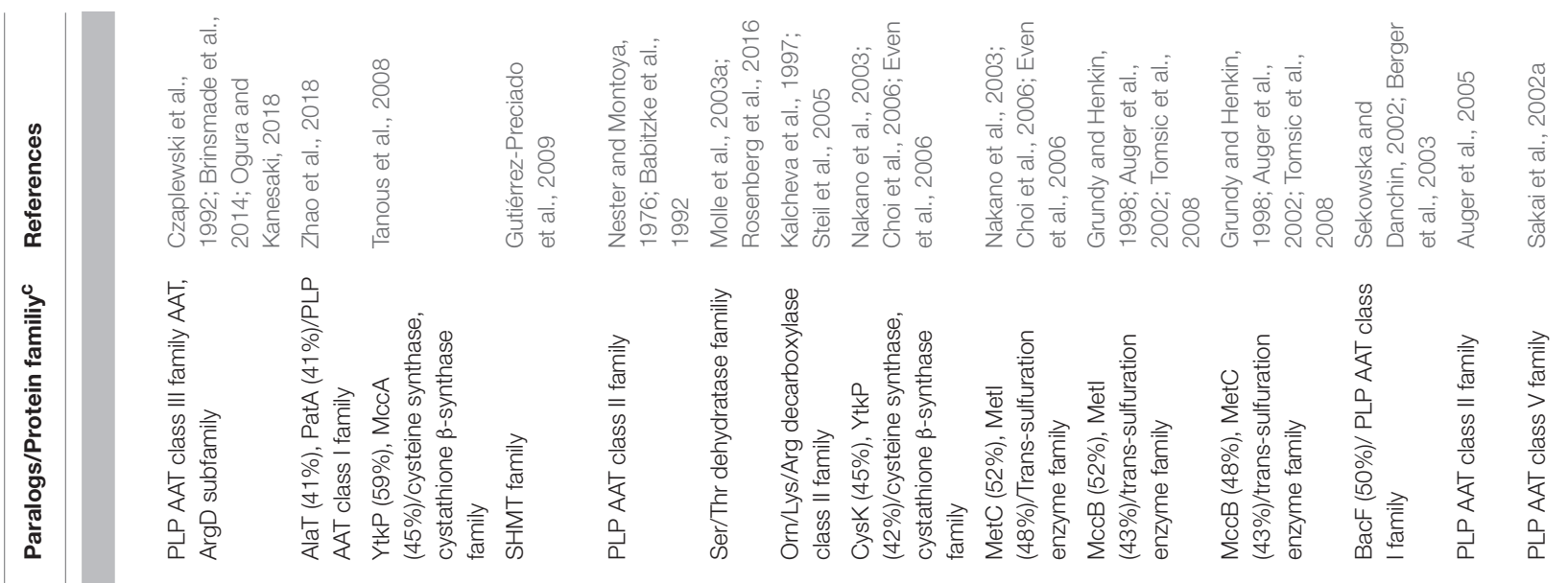

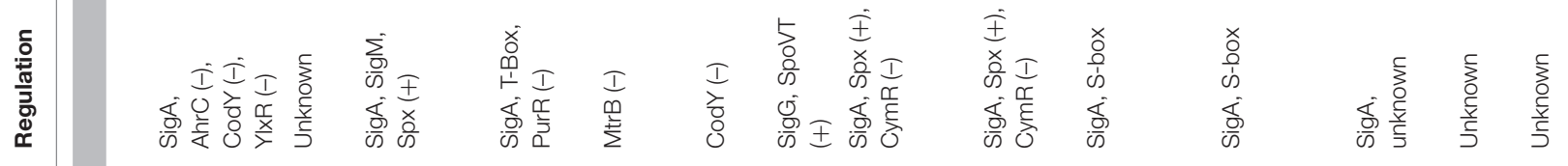

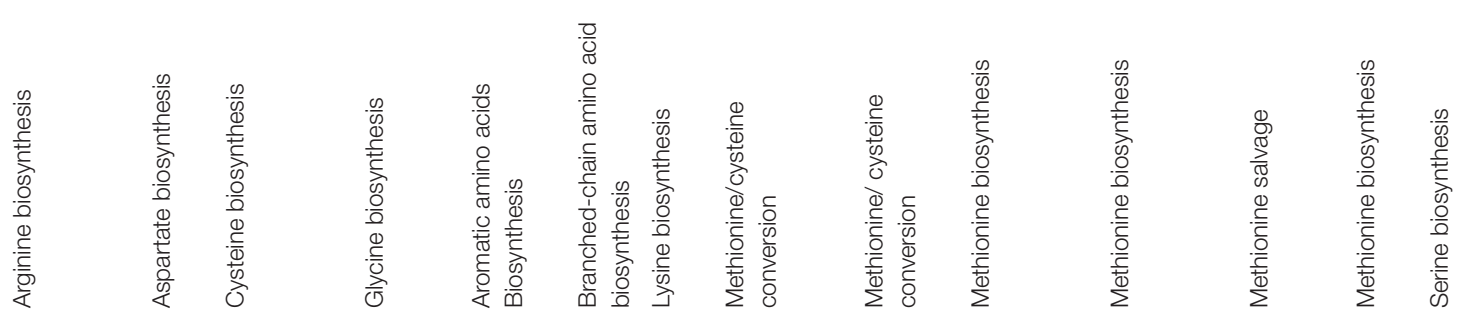

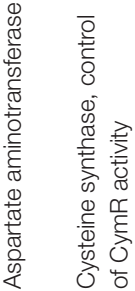
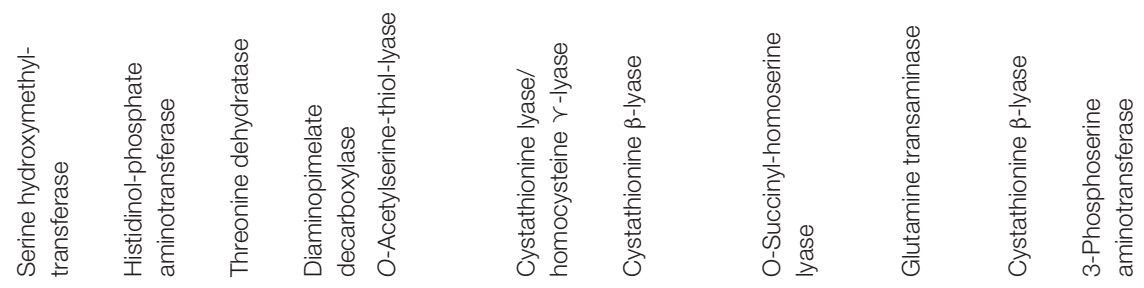<smiles>C1CCCC1</smiles>

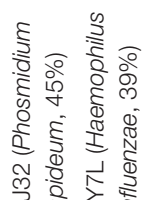

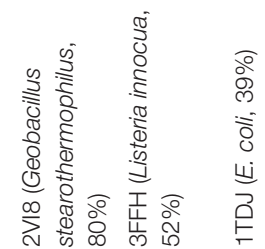

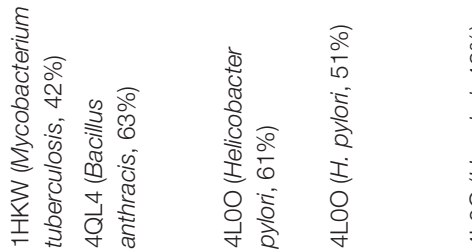

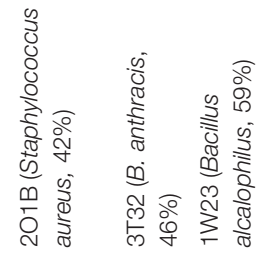
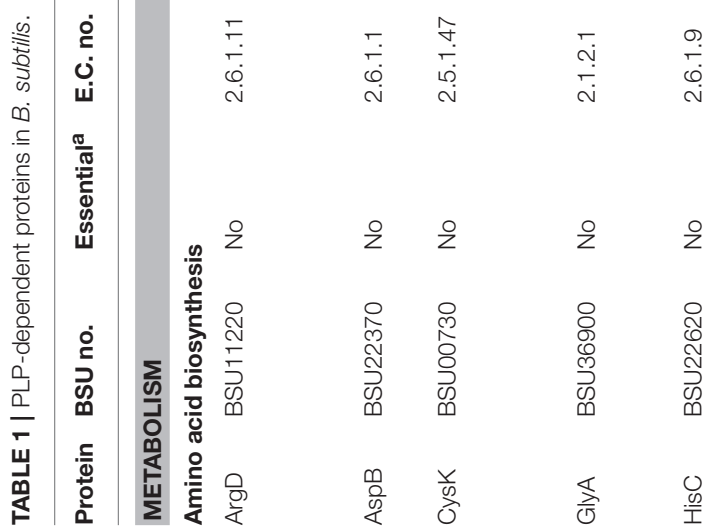

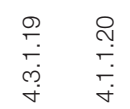

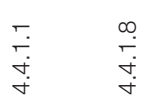

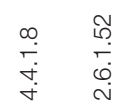

요

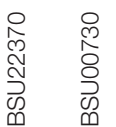

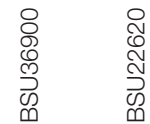

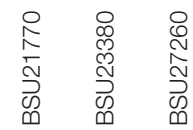

$\begin{array}{ll}0 & \infty \\ \stackrel{0}{N} & \infty \\ N & \infty \\ N & 5 \\ 0 & 0 \\ 0 & \infty\end{array}$

0
$\infty$
$\infty$
5
0
0

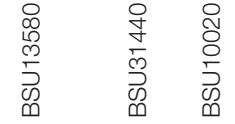

$\frac{m}{0}$
$\frac{0}{0}$
$\frac{0}{0}$

$\frac{2}{5}$

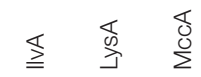

罟䔔

is

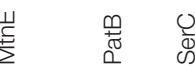




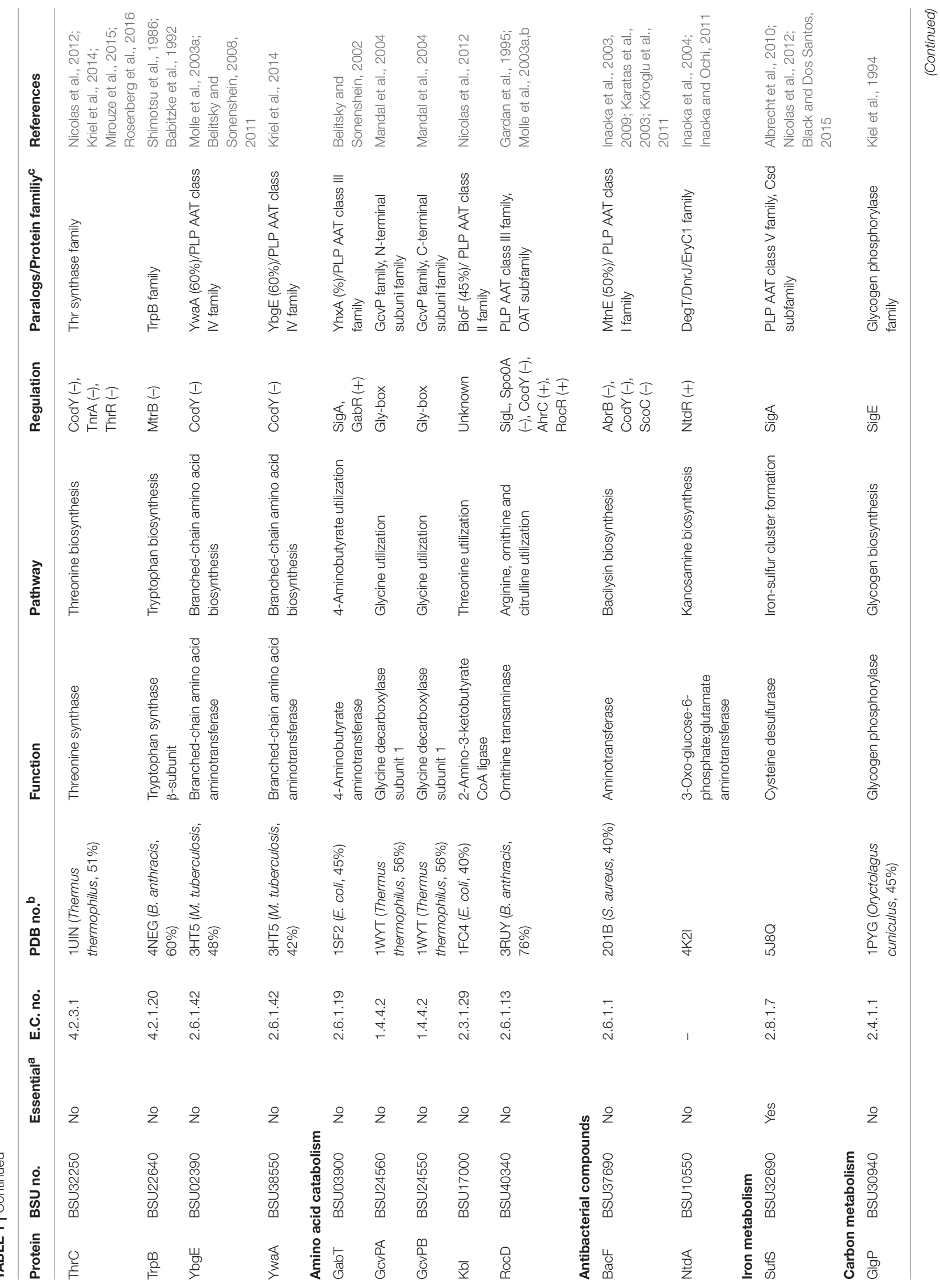




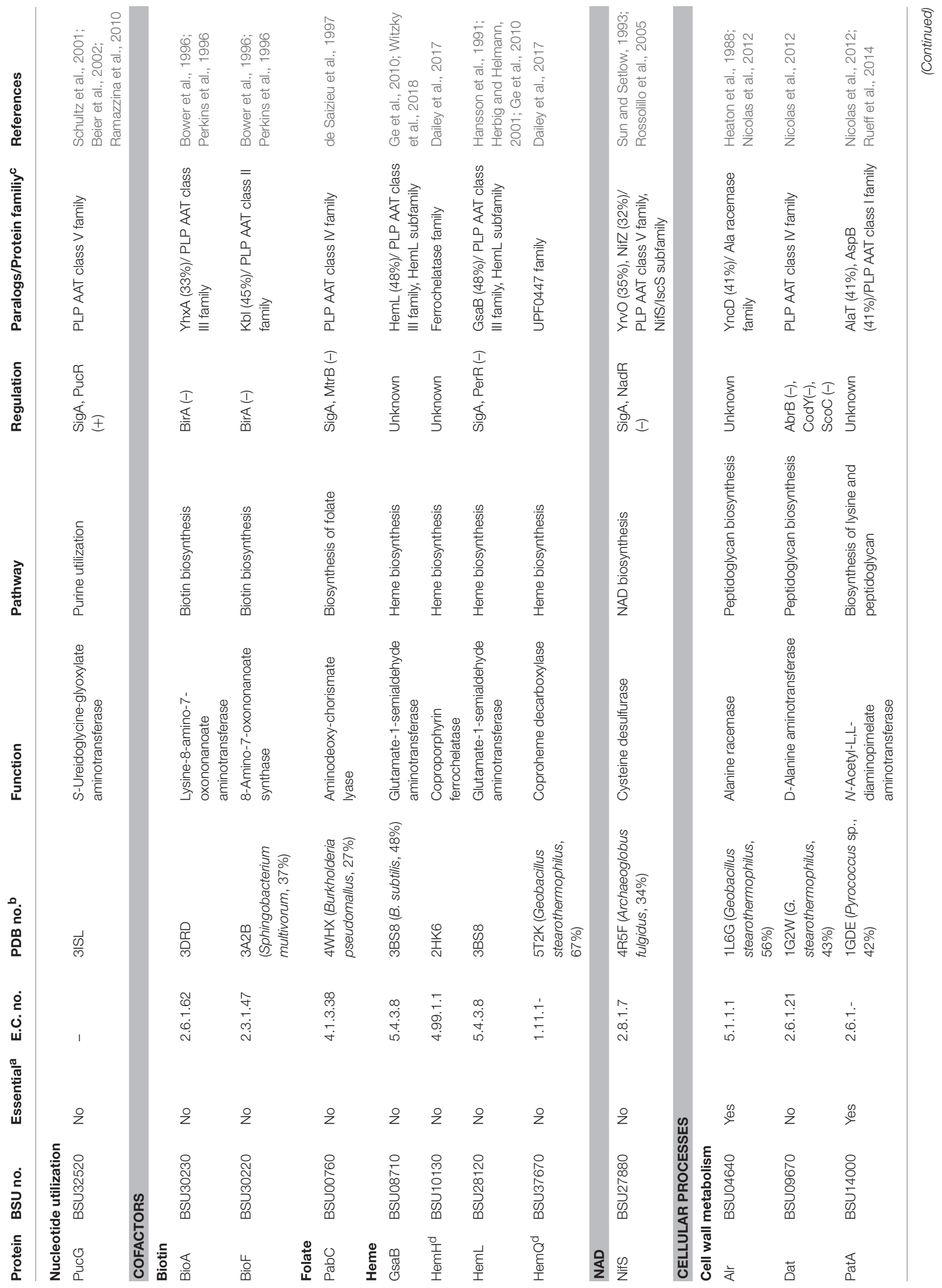




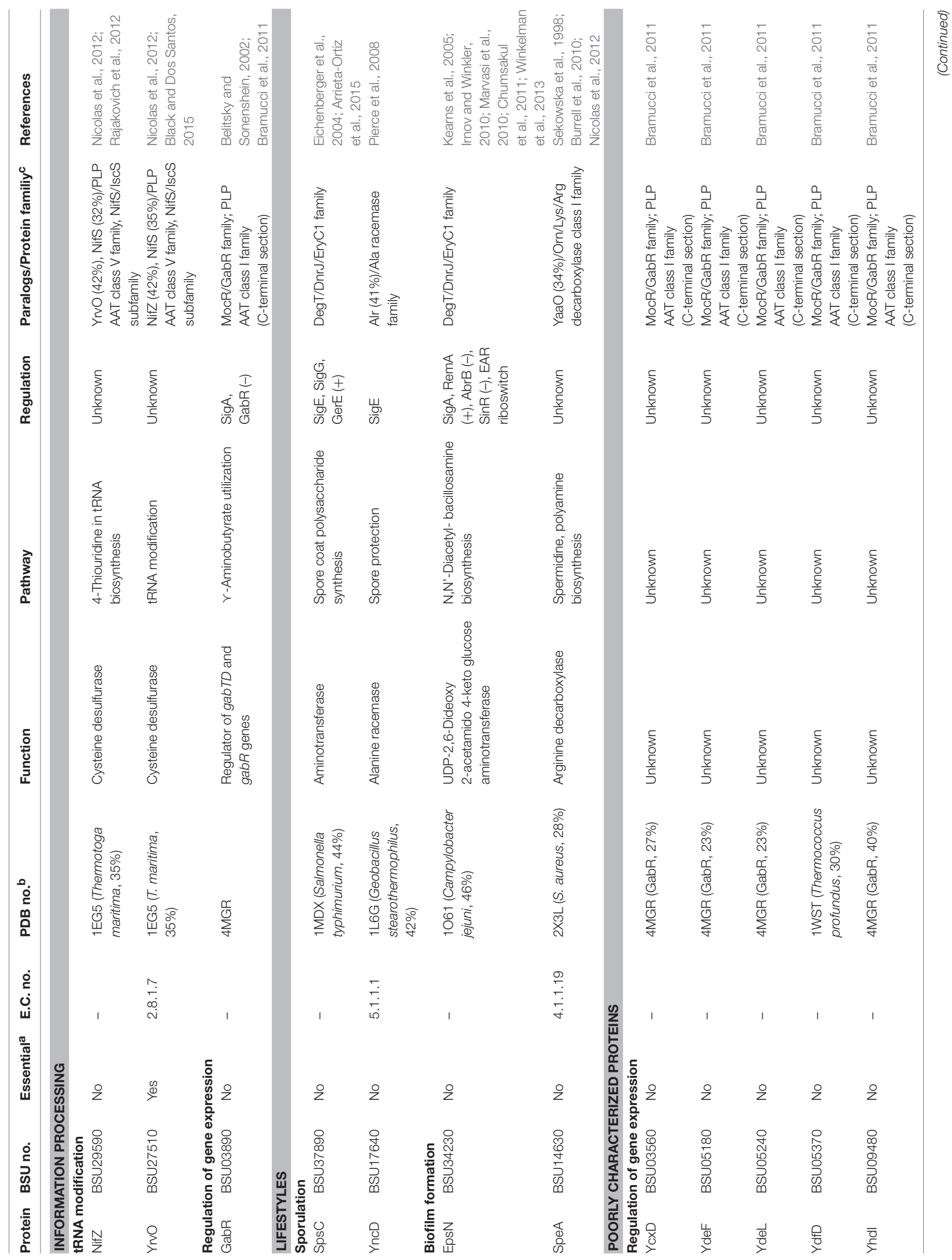




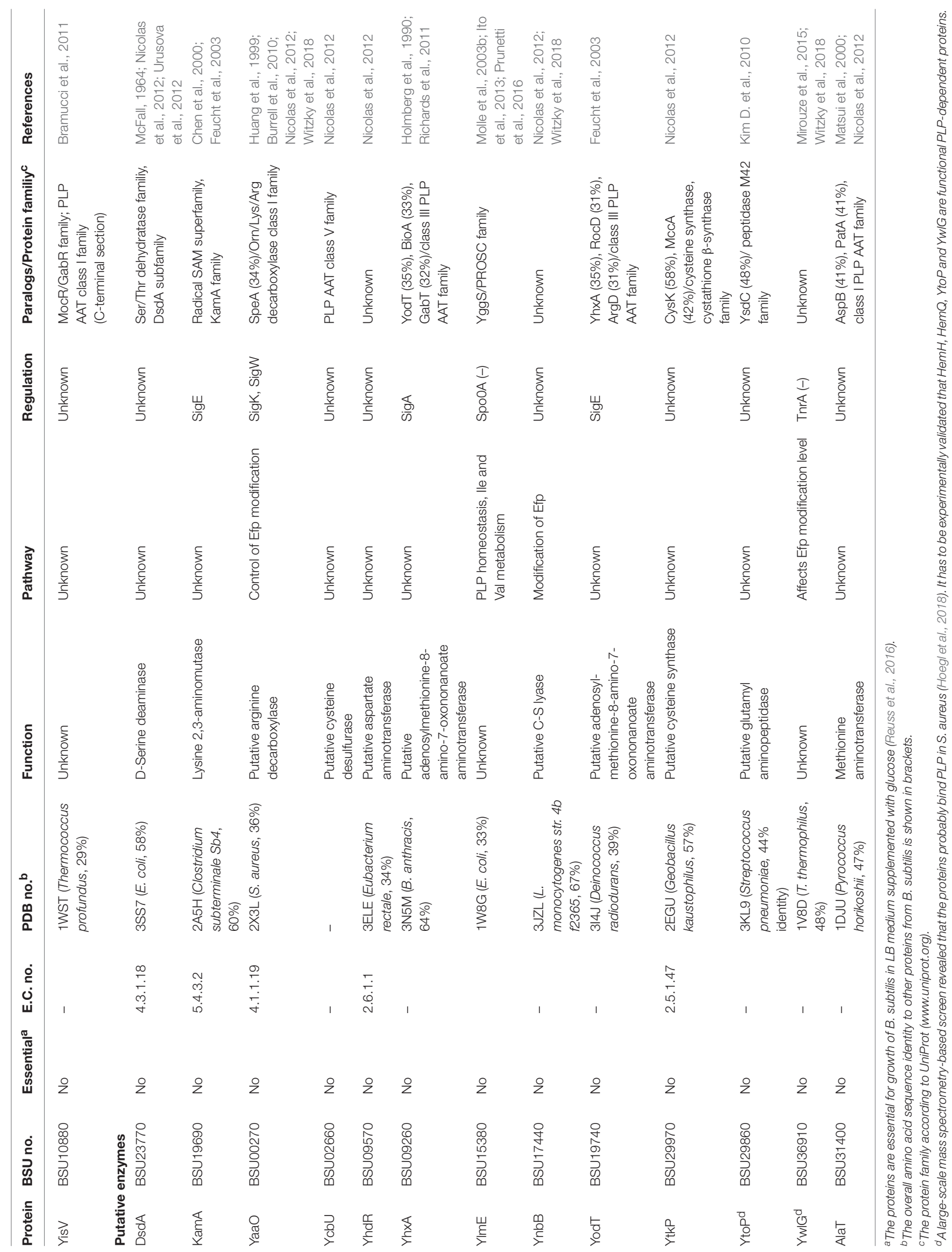



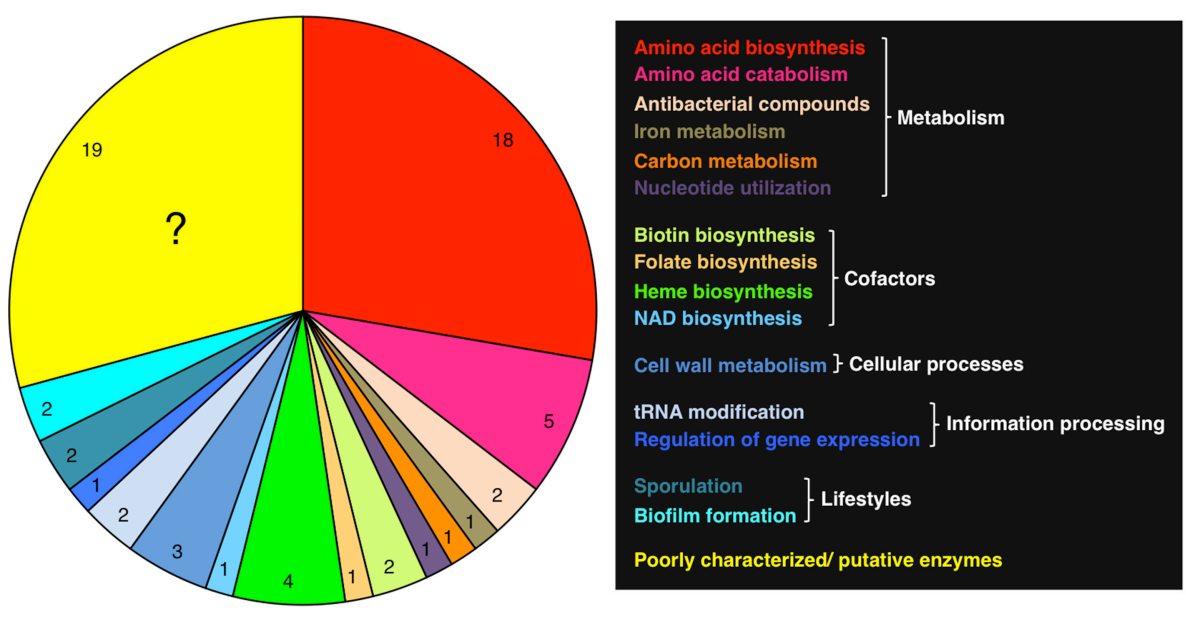

FIGURE 2 | Functional distribution of PLP-dependent proteins in B. subtilis. See Table 1 for more information.

and Streptomyces species and inhibits cell wall synthesis in microorganisms (Dolak et al., 1980; Milner et al., 1996; Inaoka et al., 2004; Inaoka and Ochi, 2011; Vetter et al., 2013). The PLP-dependent enzymes SufS, GlgP, and PucG are involved in iron-sulfur cluster formation, glycogen biosynthesis, and purine utilization, respectively (Table 1). Homologs of SufS and GlgP are also present in E. coli ( 48 and $44 \%$ overall sequence identity, respectively). However, in $B$. subtilis the glycogen phosphorylase seems to be involved in a sporulation-specific process because the $g \lg P$ gene is expressed early during sporulation in the mother cell (Kiel et al., 1994). Glycogen biosynthesis exclusively occurs in the presence of carbon sources allowing efficient sporulation (Kiel et al., 1994). Eight PLP-dependent enzymes are involved in the biosynthesis of the co-factors biotin, folate, heme and NAD (Table 1). While the biochemical and structural characterization of BioA, BioF, PabC, GsaB, HemL, and NifS revealed that the proteins require PLP for enzyme activity, it has to be investigated whether HemH and HemQ are bona fide PLP-dependent proteins. HemH and HemQ were recently identified in a mass spectrometry approach in the Gram-positive pathogen Staphylococcus aureus (Hoegl et al., 2018). B. subtilis possesses in total five PLP-dependent enzymes (Alr, Dat, PatA, NifZ, and YrvO) that are involved in cell wall metabolism and in information processing (Table 1). The alanine racemase Alr, the D-alanine aminotransferase Dat and the N-acetyl-L,Ldiaminopimelate aminotransferase PatA generate precursors for the peptidoglycan of the cell wall. The tRNA-modifing enzymes NifZ and YrvO are both cysteine desulfurases that are active in biosynthesis of 4-thiouridine and 2-thiouridine, respectively, for the formation of modified tRNA molecules. YrvO transfers sulfur to the TrmU tRNA methyltransferase, which is essential for 2thiouridine biosynthesis (Black and Dos Santos, 2015). Finally, four PLP-dependent enzymes play a role in sporulation and biofilm formation in B. subtilis (Table 1). While it has been shown that $\mathrm{Sps}$ proteins such as $\mathrm{SpsC}$ are required for spore germination (Cangiano et al., 2014), the role of the alanine racemase $\mathrm{YncD}$ in sporulation is currently unkown. The two biofilm-related enzymes, the arginine decarboxylases SpeA and the UDP-2,6dideoxy-2-acetamido-4-keto-glucose aminotransferase EpsN are important for biosynthesis of polyamines such as spermidine and extracellular polysaccharides (Burrell et al., 2010; Marvasi et al., 2010). Indeed, B. subtilis strains lacking either SpeA or EpsN are defective in biofilm formation (Burrell et al., 2010; Pozsgai et al., 2012). SpeA also possesses a paralog (YaaO, 34\% overall sequence identity), However, this proteins does not seem to be involved in biofilm formation (see below). To conclude, B. subtilis possesses several PLP-dependent enzymes that are involved in different cellular processes. Moreover, many PLP-dependent enzymes do have paralogs that have similar activities or fulfill specific functions in the cell, probably due to specialization during evolution (Table 1).

\section{PLP-DEPENDENT TRANSCRIPTION FACTORS IN BACILLUS SUBTILIS}

B. subtilis possesses seven PLP-dependent DNA-binding transcription factors of which only one has been intensively characterized (see below; Table 1). The PLP-dependent transcription factors belong to the MocR-subfamily and contain a GntR-family DNA-binding domain at the N-terminus and an aminotransferase-like sensory domain at the C-terminus (Bramucci et al., 2011; Milano et al., 2015; Tramonti et al., 2015, 2017; Suvorova and Rodionov, 2016). The MocR-familytype PLP-dependent transcription factors that have been characterized are involved in controlling the expression of genes involved in PLP, $\gamma$-aminobutyrate, ecotoine, and taurine metabolism (Suvorova and Rodionov, 2016; Schulz et al., 2017; Tramonti et al., 2018). B. subtilis can utilize $\gamma$-aminobutyrate (GABA) as a source of nitrogen (Belitsky and Sonenshein, 2002). The catabolism of GABA requires the activities of the GABA aminotransferase GabT and the succinic semi-aldehyde dehydrogenase GabD that are encoded in the bicistronic gabT-gabD operon. The MocR-family-type regulator GabR 
activates the transcription of the gabT and gabD genes in a PLPand GABA-dependent manner (Belitsky and Sonenshein, 2002; Belitsky, 2004a). The protein also binds to the gabR promoter and represses $g a b R$ transcription in the absence of GABA (Belitsky and Sonenshein, 2002; Edayathumangalam et al., 2013). Structual analysis of GabR revealed that the aminotransferase-like activity at the C-terminus of the protein is not essential for its function as a transcription regulator (Edayathumangalam et al., 2013). It has also been shown that the formation of an external aldimine between GABA and PLP causes a conformational transition from the open form to a closed form in the aminotransferase domain of GabR, triggering transcription activation of the gabT-gabD operon (Okuda et al., 2015a; Milano et al., 2017; Park et al., 2017; Wu et al., 2017). Moreover, the dimerization of the C-terminal domain of GabR enables the N-terminal domain to bind to DNA and the $\mathrm{N}$-terminal domain controls the binding specificity of the effector domain (Okuda et al., 2015b). The analysis of the interaction between GabR and DNA revealed that two cognate binding sites and the bendability of the interjacent DNA sequence are important for transcription factor binding (Al-Zyoud et al., 2016; Amidani et al., 2017). To conclude, the biochemical and structural characterization of the B. subtilis GabR transcriptional regulator has uncovered mechanistic insights into the MocRfamily-type PLP-dependent transcription factors and provides the basis for the characterization of the remaining six putative PLP-dependent DNA-binding transcription factors YcxD, YdeF, YdeL, YdfD, YhdI, and YisV from B. subtilis. Their characterization will presumably uncover novel metabolic pathways and transport systems (Suvorova and Rodionov, 2016).

\section{POORLY CHARACTERIZED PLP-DEPENDENT ENZYMES}

In addition to the 6 transcription factors whose DNA-binding activities depend on PLP and additional unknown effectors (see above), B. subtilis possesses several poorly characterized PLPdependent enzymes (Table 1; Figure 2). The DsdA protein from B. subtilis shows about $58 \%$ overalls sequence identity with the E. coli D-serine deaminase (D-serine ammonia lyase) DsdA, which catalyzes the deamination of $\mathrm{D}$-serine to form pyruvate and ammonia (Gale and Stephenson, 1938; McFall, 1964). The PLP-dependency and the structure of the enzyme from E. coli have been determined (Schnackerz et al., 1999; Urusova et al., 2012). Phylogenetic analyses suggest that the E. coli and B. subtilis $\mathrm{D}$-serine deaminases and threonine synthases with similarities in the catalytic mechanisms may have evolved from a common ancestor (Parsot, 1986). The primary function of DsdA seems to be the detoxification of D-serine, which inhibits bacterial growth because it is a competitive antagonist of $\beta$-alanine in the pantothenate (vitamin B5) biosynthetic pathway, generating the precursor for coenzyme A biosynthesis (Cosloy and McFall, 1973). Previously, it has also been shown that E. coli mutants constitutively expressing DsdA are able to use D-serine as the sole source of carbon and nitrogen (Bloom and McFall, 1975). In $B$. subtlilis the $d s d A$ gene is located in the $y q j P-y q j Q-d s d A-$ coaA-yqjT operon, containing three genes of unknown function as well as the $d s d A$ and coaA genes, of which the latter encodes the major pantothenate kinase CoaA (Ogata et al., 2014). The genetic context of the $d s d A$ gene strongly suggests that the $\mathrm{D}$-serine deaminase may be involved in the detoxification of $\mathrm{D}$-serine that probably also interferes with pantothenate synthesis in B. subtilis. The presence of a D-serine deaminase may be explained by the fact that L-serine is more rapidly racemized than most other amino acids (Reitzer, 2005). It will be interesting to elucidate whether overproduction of DsdA allows B. subtilis to grow with $D$-serine as the sole source of carbon and nitrogen and whether DsdA is involved in the detoxification of D-serine.

The B. subtilis KamA enzyme shows about $60 \%$ overalls sequence identity with the PLP-, S-adenosyl-L-methionine and $[4 \mathrm{Fe}-4 \mathrm{~S}]$-dependent lysine-2,3-aminomutase from the obligate anaerobe bacterium Clostridium subterminale (Table 1) (Lepore et al., 2005). The lysine-2,3-aminomutase catalyzes the converstion of L-lysine to L- $\beta$-lysine, which is the first step in the anaerobic degradation of lysine in clostridia (Chirpich et al., 1970). In vitro characterization of KamA from B. subtilis revealed that enzyme also catalyzes the conversion of L-lysine to L- $\beta$ lysine under anaerobic conditions (Chen et al., 2000). The KamA enzyme is only produced during sporulation of B. subtilis (Feucht et al., 2003). Therefore, the enzyme does not seem to play a role during vegetative growth. The lysine-2,3-aminomutase EpmB from $E$. coli, which shows about $31 \%$ overalls sequence identity with KamA from B. subtilis, has low lysine-2,3-aminomutase activity, indicating that L-lysine does not seem to be the natural substrate (Chen et al., 2000; Yanagisawa et al., 2010). Recently, it has been shown that the E. coli lysine-2,3-aminomutase EpmB enhances the lysylation of the elongation factor EF-P by the aminoacyl-tRNA synthetase GenX (Yanagisawa et al., 2010). The lysylation of EF-P is a post-translational modification that is essential for cell survival (Yanagisawa et al., 2010; Park et al., 2012). However, the physiological function of the lysine-2,3-aminomutase KamA from B. subtilis remains to be determined.

The B. subtilis YaaO enzyme, which belongs to class I Orn/Lys/Arg decarboxylases, encodes a putative arginine decarboxylase (Table 1). Arginine decarboxylases are important for biosynthesis of polyamines such as spermidine, substances that are crucial for biofilm formation (Burrell et al., 2010). The B. subtilis arginine decarboxylase SpeA, which can be considered as a paralog of YaaO ( $34 \%$ overall sequence identity), is indeed essential for the synthesis of polyamines and thus biofilm formation (see above) (Burrell et al., 2010). However, no biofilmrelated phenotype has been reported so far for a B. subtilis mutant lacking YaaO. Recently, it has been reported that $\mathrm{YaOO}$ and two other proteins of unknown function (YfkA and YwlG, see below) influence the level of the post-translational aminopentanol modification of the elongation factor EF-P (Witzky et al., 2018). However, the precise role of $\mathrm{YaaO}$ in the modification of EF-P in B. subtilis remains to be elucidated.

The uncharacterized PLP-dependent proteins YcbU, AlaT, YhxA, and its paralog YodT are probably PLP-dependent amino acid transferases (Table 1). YcbU might be a cysteine desulfurase that is involved in co-factor biosynthesis (Mihara and Esaki, 2002). However, it remains to be elucidated whether YcbU is functional in B. subtilis because a mutant lacking YcbU shows no obvious phenotype (Koo et al., 2017). AlaT is similar 
to PLP-dependent methionine amino acid transferases and the protein shares about $47 \%$ overall sequence identity with an amino acid transferase from Pyrococcus horikoshii that acts on aromatic amino acids (Matsui et al., 2000). However, not experimental evidence supporting the annotation of AlaT is available. Both, YhxA and YodT are annotated as putative adenosylmethionine8-amino-7-oxononanoate aminotransferases, enzymes that were shown to be involved in biotin biosynthesis in bacteria (Izumi et al., 1975). YhxA shares about 35 and 33\% sequence identity with YodT and BioA, respectively. The PLP-dependent lysine8-amino-7-oxononanoate aminotransferase BioA is required for biotin biosynthesis in B. subtilis (Table 1). Therefore, it is tempting to speculate that YhxA and YodT are also involved in biotin metabolism in this organism. The expression of the $y h x A$ and yodT genes depends on SigA and on the sporulationspecific sigma factor SigE, respectively. Therefore, these enzymes seem to be active in different cellular differentiation processes of B. subtilis.

The B. subtilis YlmE protein of unknown function shows about $33 \%$ overall sequence identity with the YggS protein from E. coli. Recently, it has been shown that YggS is a PLP-binding protein, which belongs to a highly conserved COG0325 protein family and exists in almost all kingdoms of life, including bacteria, fungi and animals (Ito et al., 2013). The high conservation of YggS indicates that the protein fulfills an important function in bacteria. Indeed, the lack of YggS in E. coli affects balance of PLP homeostasis, sensitivity toward the $\mathrm{B} 6$ vitamer $\mathrm{PN}$ and perturbation of biosynthesis of branched-chain amino acids (Prunetti et al., 2016). Similar phenotypes have been associated to a mutant strain of Synechococcus elongatus PCC 7942 lacking the pipY gene, which encodes a COG0325 homolog (Labella et al., 2017; Tremiño et al., 2017). It will be very interesting to elucidate the precise function of COG0325 homologs in controlling vitamin B6 homeostasis.

The proteins YhdR, YnbB, and YwlG cannot be assigned to a specific protein family (Table 1). YhdR shares $34 \%$ overall sequence identity with an amino acid transferase from Eubacterium rectale but its role in amino acid metabolism is unknown (Table 1). Interestingly, like YaaO, YnbB, and YwlG are involved in the post-translational aminopentanol modification of the elongation factor EF-P (Witzky et al., 2018). While YwlG influences the level of the post-translational modification, YnbB seems to be required for the modification. The precise function of the proteins in controlling the activity of the elongation factor EF$\mathrm{P}$ in $B$. subtilis needs further investigation. Moreover, it remains to be experimentally determined whether the function of YwlG depends on PLP.

The YtkP protein is a putative cysteine synthase that shares sequence similarity with the bifunctional cysteine synthase CysK and the $O$-acetylserine-thiol lyase MccA (Table 1). Since a cysK $m c c A$ double mutant is auxotrophic for cysteine, YtkP does not seem to be involved in cysteine biosynthesis. Thus, the function of YtkP remains elusive. The YtoP protein has been annotated as a putative glutamyl aminopeptidase because it shares about $44 \%$ overall sequence identity with PepA, a protease from Streptococcus pneumoniae that has been structurally and biochemically analyzed (Kim D. et al., 2010). Interestingly, YsdC, the paralog of YtoP ( $44 \%$ overall sequence identity), is annotated as an endo-1,4- $\beta$-glucanase (Table 1). Therefore, it is tempting to speculate whether YtoP is indeed involved in protein turnover. The binding of PLP to YtoP has to be experimentally validated. To conclude, B. subtilis contains several poorly characterized PLP-dependent proteins, which need to be studied in the future.

\section{CONCLUSIONS AND FUTURE PERSPECTIVES}

For a complete understanding of the vitamin B6 metabolism of $B$. subtilis it is crucial to identify and characterize all the proteins that require the essential co-factor to fulfill their function. However, even for well-studied model bacteria like B. subtilis the complete set of the enzymes involved in vitamin B6 metabolism and the PLP-dependent proteins remains to be identified. Several bioinformatics-driven approaches have been performed to identify and classify PLP-dependent enzymes (Percudani and Peracchi, 2003, 2009). Even though the PLP-dependent proteins often show low sequence similarities, using sensitive Hidden Markov Model-base sequence similarity searches PLP-dependent proteins can be identified (Yoon, 2009). However, in case the protein has a fold that is different from the known PLPdependent fold it is difficult to identify novel PLP-dependent proteins by sequence comparison. Even though structural similarity searches allowed assigning the PLP-dependent proteins to five distinct fold types (Mehta et al., 1993; Mehta and Christen, 2000; Catazaro et al., 2014), other approaches have to be pursued to uncover the full repertoire of PLP-dependent enzymes in a given organism. Indeed, mass spectrometry and biochemical approaches have been performed to identify proteins that were modified by PLP (Simon and Allison, 2009; Whittaker et al., 2015; Wu et al., 2018). As described above, a recent mass spectrometry approach identified proteins in the Gram-positive pathogen $S$. aureus that might depend on the B6 vitamer PLP (Hoegl et al., 2018). It will be interesting to evaluate whether the same approach will lead to the identification of novel PLPdependent proteins in B. subtilis and related bacteria. Moreover, the transport systems for the uptake and export of the B6 vitamers $\mathrm{PN}$ and PL have to be identified by B. subtilis. The phosphatase involved in the dephosphorylation of PNP is so far unknown (Commichau et al., 2014, 2015). Furthermore, the function of the conserved YlmE protein (YggS in E. coli) in vitamin B6 homeostasis has to be studied. Finally, it has to be elucidated how the PLP molecules are delivered to their target proteins.

\section{SPECIALITY SECTION}

PLP-Dependent Enzymes: Extraordinary Versatile Catalysts and Ideal Biotechnological Tools for the Production of Unnatural Amino Acids and Related Compounds, in Process and Industrial Biotechnology, a section of the journal Frontiers in Bioengineering and Biotechnology. 


\section{AUTHOR CONTRIBUTIONS}

BR, JR, and FC performed the database search. FC coordinated the work and wrote the manuscript with input from all authors.

\section{FUNDING}

This work was supported by the Fonds der Chemischen Industrie (to FC), the Max-Buchner-Forschungsstiftung (MBFSSt 3381 to FC), and the Deutsche Forschungsgemeinschaft (DFG grants CO 1139/1-2 and GSC 226/2 to FC and JR, respectively). This project

\section{REFERENCES}

Acevedo-Rocha, C. G., Gronenberg, L., Mack, M., Commichau, F. M., and Genee, H. J. (2019). Microbial cell factories for the sustainable manufacturing of $B$ vitaminas. Curr. Opin. Biotechnol. 56, 18-29. doi: 10.1016/j.copbio.2018.07.006

Albrecht, A. G., Netz, D. J., Miethke, M., Pierik, A. J., Burghaus, F., Lill, R., et al. (2010). SufU is an essential iron-sulfur cluster scaffold protein in Bacillus subtilis. J. Bacteriol. 192, 1643-1651. doi: 10.1128/JB. 01536-09

Al-Zyoud, W. A., Hynson, R. M., Ganuelas, L. A., Coster, A. C., Duff, A. P., Baker, M. A., et al. (2016). Binding of transcription factor GabR to DNA requires recognition of DNA shape at a location distinct from its cognate binding site. Nucleic Acids Res. 44, 1411-1420. doi: 10.1093/nar/ gkv1466

Amidani, D., Tramonti, A., Canosa, A. V., Campanini, B., Maggi, S., Milano, T., et al. (2017). Study of DNA binding and bending by Bacillus subtilis GabR, a PLP-dependent transcription factor. Biochim. Biophys. Acta Gen. Subj. 1861, 3474-3489. doi: 10.1016/j.bbagen.2016.09.013

Arrieta-Ortiz, M. L., Hafemeister, C., Bate, A. R., Chu, T., Greenfield, A., Shuster, B., et al. (2015). An experimentally supported model of the Bacillus subtilis global transcriptional regulatory network. Mol. Syst. Biol. 11:839. doi: $10.15252 / \mathrm{msb} .20156236$

Auger, S., Gomez, M. P., Danchin, A., and Martin-Verstraete, I. (2005). The PatB protein of Bacillus subtilis is a C-S-lyase. Biochimie 87, 231-238. doi: 10.1016/j.biochi.2004.09.007

Auger, S., Yuen, W. H., Danchin, A., and Martin-Verstraete, I. (2002). The metIC operon involved in methionine biosynthesis in Bacillus subtilis is controlled by transcription antitermination. Microbiology 148, 507-518. doi: 10.1099/00221287-148-2-507

Babitzke, P., Gollnick, P., and Yanofsky, C. (1992). The mtrAB operon of Bacillus subtilis encodes GTP cyclohydrolase I (MtrA), an enzyme involved in folic acid biosynthesis, and MtrB, a regulator of tryptophan biosynthesis. J. Bacteriol. 174, 2059-2064. doi: 10.1128/jb.174.7.2059-2064.1992

Beaudoin, G. A., and Hanson, A. D. (2016). A guardian angel phosphatase for mainline carbon metabolism. Trends Biochem. Sci. 41, 893-894. doi: 10.1016/j.tibs.2016.08.005

Beier, L., Nygaard, P., Jarmer, H., and Saxild, H. H. (2002). Transcription analysis of the Bacillus subtilis PucR regulon and identification of a cis-acting sequence for PucR-regulated expression of genes involved in purine catabolism. J. Bacteriol. 184, 3232-3241. doi: 10.1128/JB.184.12.3232-3241.2002

Belitsky, B. R. (2004a). Bacillus subtilis GabR, a protein with DNA-binding and aminotransferase domains, is a PLP-dependent transcriptional regulator. J. Mol. Biol. 340, 655-664. doi: 10.1016/j.jmb.2004.05.020

Belitsky, B. R. (2004b). Physiological and enzymological interaction of Bacillus subtilis proteins required for de novo pyridoxal $5^{\prime}$-phosphate biosynthesis. J. Bacteriol. 186, 1191-1196. doi: 10.1128/JB.186.4.1191-1196.2004

Belitsky, B. R. (2014). Role of PdxR in the activation of vitamin B6 biosynthesis in Listeria monocytogenes. Mol. Microbiol. 92, 1113-1128. doi: 10.1111/mmi.12618

Belitsky, B. R., and Sonenshein, A. L. (2002). GabR, a member of a novel protein family, regulates the utilization of gamma-aminobutyrate in Bacillus subtilis. Mol. Microbiol. 45, 569-583. doi: 10.1046/j.1365-2958.2002. 03036.x has received funding from the European Union's Horizon 2020 research and innovation programme under grant agreement No 720776.

\section{ACKNOWLEDGMENTS}

We are grateful to members of the Commichau laboratory for fruitful comments and suggestions. We also acknowledge the foundational work on the metabolism of vitamin B6 in bacteria and other organisms that was published beforehand and cannot be fully covered because of the limit of references.

Belitsky, B. R., and Sonenshein, A. L. (2008). Genetic and biochemical analysis of CodY-binding sites in Bacillus subtilis. J. Bacteriol. 190, 1224-1236. doi: 10.1128/JB.01780-07

Belitsky, B. R., and Sonenshein, A. L. (2011). Roadblock repression of transcription by Bacillus subtilis CodY. J. Mol. Biol. 411, 729-743. doi: 10.1016/j.jmb.2011.06.012

Berger, B. J., English, S., Chan, G., and Knodel, M. H. (2003). Methionine regeneration and aminotransferases in Bacillus subtilis, Bacillus cereus, and Bacillus anthracis. J. Bacteriol. 185, 2418-2431. doi: 10.1128/JB.185.8.2418-2431.2003

Bilski, P., Li, M. Y., Ehrenshaft, M., Daub, M. E., and Chingell, C. F. (2000). Vitamin B6 (pyridoxine) and its derivatives are efficient singlet oxygen quenchers and potential fungal antioxidants. Photochem. Photobiol. 71, 129-134. doi: 10.1562/ 0031-8655(2000)071<0129:SIPVBP > 2.0.CO;2

Black, K. A., and Dos Santos, P. C. (2015). Abbreviated pathway for biosynthesis of 2-thiouridine in Bacillus subtilis. J. Bacteriol. 197, 1952-1962. doi: 10.1128/JB.02625-14

Bloom, F. R., and McFall, E. (1975). Isolation and characterization of D-serine deaminase constitutive mutants by utilization of $\mathrm{D}$-serine as sole carbon or nitrogen source. J. Bacteriol. 121, 1078-1084.

Boschi-Muller, S., Azza, S., Pollastro, D., Corbier, C., and Branlant, G. (1997). Comparative enzymatic properties of GapB-encoded erythrose-4-P dehydrogenase of Escherichia coli and phosphorylating glyceraldehyde-3-phosphate dehydrogenase. J. Biol. Chem. 272, 15106-15112. doi: $10.1074 / j b c .272 .24 .15106$

Bower, S., Perkins, J. B., Yocum, R. R., Howitt, C. L., Rahaim, P., and Pero, J. (1996). Cloning, sequencing, and characterization of the Bacillus subtilis biotin biosynthetic operon. J. Bacteriol. 178, 4122-4130. doi: $10.1128 / \mathrm{jb}$.178.14.4122-4130.1996

Bramucci, E., Milano, T., and Pascarella, S. (2011). Genomic distribution and heterogeneity of MocR-like transcriptional factors containing a domain belonging to the superfamily of the pyridoxal-5'-phosphate dependent enzymes of fold type I. Biochem. Biophys. Res. Commun. 415, 88-93. doi: 10.1016/j.bbrc.2011.10.017

Brinsmade, S. R., Alexander, E. L., Livny, J., Stettner, A. J., Segrè, D., Rhee, K. Y., et al. (2014). Hierarchical expression of genes controlled by the Bacillus subtilis global regulatory protein CodY. Proc. Natl. Acad. Sci. U.S.A. 111, 8227-8232. doi: 10.1073/pnas.1321308111

Burns, K. D., Pieper, P. A., Liu, H. W., and Stankovich, M. T. (1996). Studies on the redox properties of CDP-6-deoxy-L-threo-D-glycero-4-hexulose-3-dehydrase (E1) and CDP-6-deoxy-L-threo-D-glycero-4-hexulose-3-dehydrase reductase (E3): two important enzymes involved in the biosynthesis of ascarylose. Biochemistry 35, 7879-7889. doi: 10.1021/bi960284t

Burns, K. E., Xiang, Y., Kinsland, C. L., McLafferty, F. W., and Begley, T. P. (2005). Reconstitution and biochemical characterization of a new pyridoxal5'-phosphate biosynthetic pathway. J. Am. Chem. Soc. 127, 3682-3683. doi: $10.1021 / \mathrm{ja} 042792 \mathrm{t}$

Burrell, M., Hanfrey, C. C., Murray, E. J., Stanley-Wall, N. R., and Michael, A. J. (2010). Evolution and multiplicity of arginine decarboxylases in polyamine biosynthesis and essential role in Bacillus subtilis biofilm formation. J. Biol. Chem. 285, 39224-39238. doi: 10.1074/jbc.M110. 163154 
Campbell, T. L., Daigle, D. M., and Brown, E. D. (2005). Characterization of the Bacillus subtilis GTPase YloQ and its role in ribosome function. Biochem. J. 389, 843-852. doi: 10.1042/BJ20041873

Cane, D. E., Du, S., Robinson, J. K., Hsiung, Y., and Spenser, I. D. (1999). Biosynthesis of vitamin B6: enzymatic conversion of 1-deoxy-D-xylulose5-phosphate to pyridoxol phosphate. J. Am. Chem. Soc. 121, 7722-7723. doi: $10.1021 /$ ja9914947

Cane, D. E., Hsiung, Y., Cornish, J. A., Robinson, J. K., and Spenser, I. D. (1998). Biosynthesis of vitamin B6: the oxidation of 4-(phosphohydroxy)L-threonine by PdxA. J. Am. Chem. Soc. 120, 1936-1937. doi: 10.1021/ ja9742085

Cangiano, G., Sirec, T., Panarella, C., Isticato, R., Baccigalupi, L., De Felice, M., et al. (2014). The sps gene products affect the germination, hydrophobicity, and protein adsorption of Bacillus subtilis spores. Appl. Environ. Microbiol. 80, 7293-7302. doi: 10.1128/AEM.02893-14

Catazaro, J., Caprez, A., Guru, A., Swanson, D., and Powers, R. (2014), Funtional evolution of PLP-dependent enzymes based on active-site structural similarities. Proteins 82, 2597-2608. doi: 10.1002/prot.24624

Chen, D., Ruzicka, F. J., and Frey, P. A. (2000). A novel lysine 2,3-aminomutase encoded by the yodO gene of Bacillus subtilis: characterization and the observation of organic radical intermediates. Biochem. J. 348, 539-549. doi: 10.1042/bj3480539

Chirpich, T. P., Zappia, V., Costilow, R. N., and Barker, H. A. (1970). Lysine 2,3-aminomutase. Purification and properties of a pyridoxal phosphate and S-adenosylmethionine-activated enzyme. J. Biol. Chem. 245, 1778-1789.

Choi, S. Y., Reyes, D., Leelakriangsak, M., and Zuber, P. (2006). The global regulator Spx functions in the control of organosulfur metabolism in B. subtilis. J. Bacteriol. 188, 5741-5751. doi: 10.1128/JB.00443-06

Christen, P., and Mehta, P. K. (2001). From cofactor to enzymes. The molecular evolution of pyridoxal-5'-phosphate-dependent enzymes. Chem. Rec. 1, 436-447. doi: 10.1002/tcr.10005

Chumsakul, O., Takahashi, H., Oshima, T., Hishimoto, T., Kanaya, S., Ogasawara, N., et al. (2011). Genome-wide binding profiles of the Bacillus subtilis transition state regulator $\mathrm{AbrB}$ and its homolog $\mathrm{Abh}$ reveals their interactive role in transcription regulateion. Nucleic Acids Res. 39, 414-428. doi: 10.1093/nar/gkq780

Collard, F., Baldin, F., Gerin, I., Bolsée, J., Noel, G., Graff, J., et al. (2016). A conserved phosphatase destroys toxic glycolytic side products in mammals and yeast. Nat. Chem. Biol. 12, 601-601. doi: 10.1038/nchembi o. 2104

Commichau, F. M., Alzinger, A., Sande, R., Bretzel, W., Meyer, F. M., Chevreux, B., et al. (2014). Overexpression of a non-native deoxyxylulose-dependent vitamin B6 pathway in Bacillus subtilis for the production of pyridoxine. Metab. Eng. 25, 38-49. doi: 10.1016/j.ymben.2014.06.007

Commichau, F. M., Alzinger, A., Sande, R., Bretzel, W., Reuß, D. R., Dormeyer, M., et al. (2015). Overexpression of a non-native deoxyxylulose-dependent vitamin B6 pathway in Bacillus subtilis for the production of pyridoxine. Metab. Eng. 29, 196-207. doi: 10.1016/j.ymben.2015.03.007

Cosloy, S. D., and McFall, E. (1973). Metabolism of D-serine in Escherichia coli K-12: mechanism of growth inhibition. J. Bacteriol. 114, 685-694.

Czaplewski, L. G., North, A. K., Smith, M. C., Baumberg, S., and Stockley, P. G. (1992). Purification and initial characterization of AhrC: the regulator of arginine metabolism genes in Bacillus subtilis. Mol. Microbiol. 6, 267-275. doi: 10.1111/j.1365-2958.1992.tb02008.x

Dailey, H. A., Dailey, T. A., Gerdes, S., Jahn, D., Jahn, M., O’Brian, M. R., et al. (2017). Prokaryotic heme biosynthesis: multiple pathways to a common essential product. Microbiol. Mol. Biol. Rev. 81, e00048-e00016. doi: 10.1128/MMBR.00048-16

de Saizieu, A., Vankan, P., Vockler, C., and van Loon, A. P. (1997). The trp RNA-binding attenuation protein (TRAP) regulates the steady-state levels of transcripts of the Bacillus subtilis folate operon. Microbiology 143, 979-989. doi: 10.1099/00221287-143-3-979

di Salvo, M. L., Contestabile, R., and Safo, M. K. (2011). Vitamin B6 salvage enzymes: mechanism, structure and regulation. Biochim. Biophys. Acta. 1854, 1597-1608. doi: 10.1016/j.bbapap.2010.12.006

di Salvo, M. L., Hunt, S., and Schich, V. (2004). Expression, purification, and kinetic constants for human and Escherichia coli pyridoxal kinases. Protein Expr. Purif. 36, 300-306. doi: 10.1016/j.pep.2004.04.021
Dolak, L. A., Castle, T. M., Dietz, A., and Laborde, A. L. (1980). 3-Amino3-deoxyglucose produced by a Streptomyces sp. J. Antibiot. 33, 900-901. doi: 10.7164/antibiotics.33.900

Domke, A., Großklaus, R., Niemann, B., Przyrembel, H., Richter, K., Schmidt, E., et al. (2005). Use of Vitamins in Foods - Toxicological and NutritionalPhysiological Aspects. Berlin: BfR-Wissenschaft.

Dong, Q., and Fromm, H. J. (1990). Chemical modification of adenylsuccinate synthetase from Escherichia coli by pyridoxal 5' -phosphate. Identification of an active site lysyl residue. J. Biol. Chem. 265, 6235-6240.

Drewke, C., Klein, M., Clade, D., Arenz, A., Müller, A., and Leistner, E. (1996). 4-O-phosphoryl-L-threonine, a substrate of the $\mathrm{pdxC}(\mathrm{serC})$ gene product involved in vitamin B6 biosynthesis. FEBS Lett. 390, 179-182. doi: 10.1016/0014-5793(96)00652-7

Drewke, C., Notheis, C., Hansen, U., Leistner, E., Hemscheidt, T., Hill, R. E., et al. (1993). Growth response to 4-hydroxy-L-threonine of Escherichia coli mutants blocked in vitamin B6 biosynthesis. FEBS Lett. 318, 125-128. doi: 10.1016/0014-5793(93)80005-F

Edayathumangalam, R., Wu, R., Garcia, R., Wang, Y., Wang, W., Kreinbring, C. A., et al. (2013). Crystal structure of Bacillus subtilis GabR, an autorepressor and transcriptional activator of gabT. Proc. Natl. Acad. Sci. U.S.A. 110 17820-17825. doi: 10.1073/pnas.1315887110

Eggersdorfer, M., Laudert, D., Létinois, U., McClymont, T., Medlock, J., Netscher, T., et al. (2012). One hundred years of vitamins - a success story of natural sciences. Angew. Chem. Int. Ed. Engl. 51, 12960-12990. doi: 10.1002/anie.201205886

Ehrenshaft, M., and Daub, M. E. (2001). Isolation of PDX2, a second novel gene in the pyridoxine biosynthesis pathway of eukaryotes, archaebacteria, and a subset of eubacteria. J. Bacteriol. 183, 3383-3390. doi: 10.1128/JB.183.11.3383-3390.2001

Eichenberger, P., Fujita, M., Jensen, S. T., Conlon, E. M., Rudner, D. Z., Wang, S. T., et al. (2004). The program of gene transcription for a single differentiating cell type during sporulation in Bacillus subtilis. PLoS Biol. 2:e328. doi: 10.1371/journal.pbio.0020328

El Qaidi, S., Yang, J., Zhang, J. R., Metzger, D. W., and Bai, G. (2013). The vitamin B6 pathway in Streptococcus pneumoniae is controlled by pyridoxal 5 -phosphate and the transcription factor PdxR and has an impact on ear infection. J. Bacteriol. 195, 2187-2196. doi: 10.1128/JB.00041-13

Eliot, A. C., and Kirsch, J. F. (2004). Pyridoxal phosphate enzymes: mechanistic, structural, and evolutionary considerations. Annu. Rev. Biochem. 73, 383-415. doi: 10.1146/annurev.biochem.73.011303.074021

Even, S., Burguière, P., Auger, S., Soutourina, O., Danchin, A., and MartinVerstraete, I. (2006). Global control of cysteine metabolism by CymR in Bacillus subtilis. J. Bacteriol. 188, 2184-2197. doi: 10.1128/JB.188.6.2184-2197.2006

Farrington, G. K., Kumar, A., Shames, S. L., Ewaskiewicz, J. I., Ash, D. E., and Wedler, F. C. (1993). Threonine synthase of Escherichia coli: inhibition by classical and slow-binding analogues of homoserine phosphate. Arch. Biochem. Biophys. 307, 165-174. doi: 10.1006/abbi.1993.1575

Feucht, A., Evans, J., and Errington, J. (2003). Identification of sporulation genes by genome-wide analysis of the sigmaE regulon of Bacillus subtilis. Microbiology 149, 3023-3034. doi: 10.1099/mic.0.26413-0

Fitzpatrick, T. B., Amrhein, N., Kappes, B., Macheroux, P., Tews, I., and Raschle, T. (2007). Two independent routes for de novo vitamin B6 biosynthesis: not that different after all. Biochem. J. 407, 1-13. doi: 10.1042/BJ20070765

Fitzpatrick, T. B., Moccand, C., and Roux, C. (2010). Vitamin B6 biosynthesis: charting the mechanistic landscape. ChemBioChem 11, 1185-1193. doi: $10.1002 /$ cbic. 201000084

Gale, E. F., and Stephenson, M. (1938). Factors influencing bacterial deamination: factors influencing the activity of dl-serine deaminase in Bacterium coli. Biochem. J. 32, 392-404. doi: 10.1042/bj0320392

Gardan, R., Rapoport, G., and Débarbouillé, M. (1995). Expression of the rocDEF operon involved in arginine catabolism in Bacillus subtilis. J. Mol. Biol. 249, 843-856. doi: 10.1006/jmbi.1995.0342

Ge, H., Ly, X., Fan, J., Gao, Y., Teng, M., and Niu, L. (2010). Crystal structure of glutamate-1-semialdehyde aminotransferase from Bacillus subtilis with bound pyridoxamine-5' -phosphate. Biochem. Biophys. Res. Commun. 402, 356-360. doi: $10.1016 /$ j.bbrc.2010.10.033

Ghatge, M. S., Contestabile, R., di Salvo, M. L., Desai, J. V., Gandhi, A. K., Camara, C. M., et al. (2012). Pyridoxal $5^{\prime}$-phosphate is a slow tight binding inhibitor 
of E. coli pyridoxal kinase. PLoS ONE. 7:e41680. doi: 10.1371/journal.pone. 0041680

Grundy, F., and Henkin, T. (1998). The S box regulon: a new global transcription termination control system for methionine and cysteine biosyngthesis genes in Gram-positive bacteria. Mol. Microbiol. 30, 737-749. doi: 10.1046/j.1365-2958.1998.01105.x

Gutiérrez-Preciado, A., Henkin, T. M., Grundy, F. J., Yanofsky, C., and Merino, E. (2009). Biochemical features and functional implications of the RNAbased T-box regulatory mechanism. Microbiol. Mol. Biol. Rev. 73, 36-61. doi: 10.1128/MMBR.00026-08

György, P. (1956). The history of vitamin B6. Am. J. Clin. Nutr. 4, 313-317. doi: $10.1093 /$ ajcn/4.4.313

Hansson, M., Rutberg, L., Schröder, I., and Hederstedt, L. (1991). The Bacillus subtilis hemAXCDBL gene cluster, which encodes enzymes of the biosynthetic pathway from glutamate to uroporphyrinogen III. J. Bacteriol. 173, 2590-2599. doi: 10.1128/jb.173.8.2590-2599.1991

Hartl, J., Kiefer, P., Meyer, F., and Vorholt, J. A. (2017). Longevity of major coenzymes allows minimal de novo synthesis in microorganisms. Nat. Microbiol. 2:17073. doi: 10.1038/nmicrobiol.2017.73

Heaton, M. P., Johnston, R. B., and Thompson, T. L. (1988). Controlled lysis of bacterial cells utilizing mutants with defective synthesis of D-alanine. Can. J. Microbiol. 34, 256-261. doi: 10.1139/m88-047

Herbig, A. F., and Helmann, J. D. (2001). Roles of metal ions and hydrogen peroxide in modulating the interaction of the Bacillus subtilis PerR peroxide regulon repressor with operator DNA. Mol. Microbiol. 41, 849-859. doi: 10.1046/j.1365-2958.2001.02543.x

Hoegl, A., Nodwell, M. B., Kirsch, V. C., Bach, N. C., Pfanzelt, M., Stahl, M., et al. (2018). Mining the cellular inventory of pyridoxal phosphate-dependent enzymes with functionalized cofactor mimics. Nat. Chem. 10, 1234-1245. doi: 10.1038/s41557-018-0144-2

Holmberg, C., Beijer, L., Rutberg, B., and Rutberg, L. (1990). Glycerol catabolism in Bacillus subtilis: nucleotide sequence of the genes encoding glycerol kinase (glpK) and glycerol-3-phosphate dehydrogenase (glpD). J. Gen. Microbiol. 136, 2367-2375. doi: 10.1099/00221287-136-12-2367

Huang, X., Gaballa, A., Cao, M., and Helmann, J. D. (1999). Identification of target promoters for the Bacillus subtilis extracytoplasmic function sigma factor, sigma W. Mol. Microbiol. 31, 361-371. doi: 10.1046/j.1365-2958.1999.01180.x

Huq, M. D., Tsai, N. P., Lin, Y. P., Higgins, L., and Wei, L. N. (2007). Vitamin B6 conjugation to nuclear corepressor RIP140 and its role in gene regulation. Nat. Chem. Biol. 3, 161-165. doi: 10.1038/nchembio861

Inaoka, T., and Ochi, K. (2011). Activation of dormant secondary metabolism neotrehalosadiamine synthesis by an RNA polymerase mutation in Bacillus subtilis. Biosci. Biotechnol. Biochem. 75, 618-623. doi: 10.1271/bbb.100854

Inaoka, T., Takahashi, K., Ohnishi-Kameyama, M., Yoshida, M., and Ochi, K. (2003). Guanine nucleosides guanosine $5^{\prime}$-diphosphate $3^{\prime}$-diphosphate and GTP co-operatively regulate the production of an antibiotic bacilysin in Bacillus subtilis. J. Biol. Chem. 278, 2169-2176. doi: 10.1074/jbc.M208722200

Inaoka, T., Takahashi, K., Yada, H., Yoshida, M., and Ochi, K. (2004). RNA polymerase mutation activates the production of a dormant antibiotic 3,3'neotrehalosamine via an autoinduction mechanism in Bacillus subtilis. J. Biol. Chem. 279, 3885-3892. doi: 10.1074/jbc.M309925200

Inaoka, T., Wang, G., and Ochi, K. (2009). ScoC regulates bacilysin production at the transcription level in Bacillus subtilis. J. Bacteriol. 191, 7367-7371. doi: 10.1128/JB.01081-09

Irnov, I., and Winkler, W. C. (2010). A regulatory RNA required for antitermination of biofilm and capsular polysaccharide operons in Bacillus subtilis. Mol. Microbiol. 76, 559-575. doi: 10.1111/j.1365-2958.2010.07131.x

Ito, T., Limori, J., Takayama, S., Moriyama, A., Yamauchi, Y., Hemmi, H., et al. (2013). Conserved pyridoxal protein that regulates Ile and Val metabolism. J. Bacteriol. 195, 5439-5449. doi: 10.1128/JB.00593-13

Izumi, Y., Sato, K., Tani, Y., and Ogata, K. (1975). 7,8-diaminopelargonic acid aminotransferase, an enzyme involved in biotin synthesis by microorganisms. Agric. Biol. Chem. 39, 175-181. doi: 10.1080/00021369.1975.10861584

Jansonius, J. N. (1998). Structure, evolution and action of vitamin B6-dependent enzymes. Curr. Opin. Struct. Biol. 8, 759-769. doi: 10.1016/S0959-440X(98)80096-1

Jochmann, N., Götker, S., and Tauch, A. (2011). Positive transcriptional control of the pyridoxal phosphate biosynthesis genes pdxST by the MocR-type regulatore
PdxR of Corynebacterium glutamicum ATCC 13032. Microbiology 157, 77-88. doi: $10.1099 /$ mic.0.044818-0

John, R. A. (1995). Pyridoxal phosphate dependent enzymes. Biochim. Biophys. Acta. 1248, 81-96. doi: 10.1016/0167-4838(95)00025-P

Kalcheva, E. O., Faiziev, M. M., and Malyuta, S. S. (1997). Isolation and comparative analysis of diaminopimelate decarboxylase from Streptococcus bovis and Bacillus subtilis. Mol. Gen. Mikrobiol. Virosol. 1, 34-37.

Karatas, A. Y., Cetin, S., and Ozcengiz, G. (2003). The effects of insertional mutations in comQ, comP, srfA, spo0H, spo0A and abrB genes on bycilysin biosynthesis in Bacillus subtilis. Biochim. Biophys. Acta. 1626, 51-56. doi: 10.1016/S0167-4781(03)00037-X

Kearns, D. B., Chu, F., Branda, S. S., Kolter, R., and Losick, R. (2005). A master regulator for biofilm formation by Bacillus subtilis. Mol. Microbiol. 55, 739-749. doi: 10.1111/j.1365-2958.2004.04440.x

Kiel, J. A., Boels, J. M., Beldman, G., and Venema, G. (1994). Glycogen in Bacillus subtilis: molecular characterization of an operon encoding enzymes involved in glycogen biosynthesis and degradation. Mol. Microbiol. 11, 203-218. doi: 10.1111/j.1365-2958.1994.tb00301.x

Kim, D., San, B. H., Moh, S. H., Park, H., Kim, D. Y., Lee, S., et al. (2010). Structural basis for the substrate specificity of PepA from Streptococcus pneumoniae, a dodecameric tetrahedral protease. Biochem. Biophys. Res. Commun. 391, 431-436. doi: 10.1016/j.bbrc.2009.11.075

Kim, J., and Copley, S. D. (2012). Inhibitory cross-talk upon introduction of a new metabolic pathway into an existing metabolic network. Proc. Natl. Acad. Sci. U.S.A. 109, E2856-E2864. doi: 10.1073/pnas.1208509109

Kim, J., Kershner, J. P., Novikov, Y., Shoemaker, R. K., and Copley, S. D. (2010). Three serendipitous pathways in E. coli can bypass a block in pyridoxal- $5^{\prime}$ phosphate synthesis. Mol. Sys. Biol. 6:436. doi: 10.1038/msb.2010.88

Kleemann, A., Engel, B., Kutscher, D., and Reichert, D. (2008). Pharmaceutical Substances. Syntheses, Patents, Applications of the Most Relevant APIs. Stuttgart: Thieme.

Koo, B. M., Kritikos, G., Farelli, J. D., Todor, H., Tong, K., Kimsey, H., et al. (2017) Construction and analysis of two genme-scale deletion libraries for Bacillus subtilis. Cell Syst. 4, 291-305.e7. doi: 10.1016/j.cels.2016.12.013

Köroglu, T. E., Ogülür, I., Mutlu, A., Yazgan-Karatas, A., and Ozcengiz, G. (2011). Global regulatory systems operating in bacilysin biosynthesis in Bacillus subtilis. J. Mol. Microbiol. Biotechnol. 20, 144-155. doi: 10.1159/000328639

Kraemer, K., Semba, R. D., Eggersdorfer, M., and Schaumberg, D. A. (2012). Introduction: the diverse and essential biological functions of vitamins. Ann. Nutr. Metab. 61, 185-191. doi: 10.1159/000343103

Kriel, A., Brinsmade, S. R., Tse, J. L., Tehranchi, A. K., Bittner, A. N., Sonenshein, A. L., et al. (2014). GTP dysregulation in Bacillus subtilis cells lacking (p)ppGpp results in phenotypic amino acid auxotrophy and failure to adapt to nutrient downshift and regulate biosyntiesis genes. J. Bacteriol. 196, 189-201. doi: 10.1128/JB.00918-13

Labella, J. I., Cantos, R., Espinosa, J., Forcada-Nadal, A., Rubio, V., and Contreras, A. (2017). PipY, a member of the conserved COG0325 family of PLP-binding proteins, expands the cyanobacterial nitrogen regulatory network. Front. Microbiol. 8:1244. doi: 10.3389/fmicb.2017.01244

Laber, B., Maurer, W., Scharf, S., Stepusin, K., and Schmidt, F. S. (1999). Vitamin B6 biosynthesis: formation of pyridoxine $5^{\prime}$-phosphate from 4(phosphohydroxy)-L-threonine and 1-deoxy-D-xylulose-5-phosphate by PdxA and PdxJ protein. FEBS Lett. 449, 45-48. doi: 10.1016/S0014-5793(99)0 0393-2

Lee, W. M., Elliot, J. E., and Brownsey, R. W. (2005). Inhibition of acetyl-CoA carboxylase isoforms by pyridoxal phosphate. J. Biol. Chem. 280, 41385-41843. doi: 10.1074/jbc.M510728200

Lepore, B. W., Ruzicka, F. J., Frey, P. A., and Ringe, D. (2005). The x-ray crystal structure of lysine-2,3-aminomutase from Clostridium subterminale. Proc. Natl. Acad. Sci. U.S.A. 102, 13829-13824. doi: 10.1073/pnas.0505726102

Lerma-Ortiz, C., Jeffryes, J. G., Cooper, A. J., Niehaus, T. D., Thamm, A. M., Frelin, O., et al. (2016). "Nothing of chemistry disappears in biology": the top 30 damage-prone endogenous metabolites. Biochem. Soc. Trans. 44, 961-971. doi: 10.1042/BST20160073

Liao, S., Bitoun, J. P., Nguyen, A. H., Bozner, D., Yao, X., and Wen, Z. T. (2015). Deficiency of PdxR in Streptococcus mutans affects vitamin B6 metabolism, acid tolerance response and biofilm formation. Mol. Oral Microbiol. 30, 255-268. doi: 10.1111/omi.12090 
Linster, C. L., Van Schaftingen, E., and Hanson, A. D. (2013). Metabolite damage and its repair of pre-emption. Nat. Chem. Biol. 9, 72-80. doi: $10.1038 /$ nchembio.1141

Mandal, M., Lee, M., Barrick, J. E., Weinberg, Z., Emilsson, G. M., Ruzzo, W. L., et al. (2004). A glycine-dependent riboswitch that uses cooperative binding to control gene expression. Science 306, 275-279. doi: 10.1126/science.1100829

Marvasi, M., Visscher, P. T., and Casillas Martinez, L. (2010). Exopolymeric substances (EPS) from Bacillus subtilis: polymers and genes encoding their synthesis. FEMS Microbiol. Lett. 313, 1-9. doi: 10.1111/j.1574-6968.2010.02085.x

Matsui, I., Matsui, E., Sakai, Y., Kikuchi, H., Kawarabayasi, Y., Ura, H., et al. (2000). The molecular structure of hyperthermostabole aromatic aminotransferase with novel substrate specificity from Pyrococcus horikoshii. J. Biol. Chem. 275, 4871-4879. doi: 10.1074/jbc.275.7.4871

McFall, E. (1964). Genetic structure of the D-serine deaminase system of Escherichia coli. J. Mol. Biol. 9, 746-753. doi: 10.1016/S0022-2836(64)80179-0

Mehta, P. K., and Christen, P. (2000). The molecular evolution of pyridoxal5 '-phosphate-dependent enzymes. Adv. Enzymol. Relat. Areas Mol. Biol. 74, 129-184. doi: 10.1002/9780470123201.ch4

Mehta, P. K., Hale, T. I., and Christen, P. (1993). Aminotransferase: demonstration of homology and division into evolutionary subgroups. Eur. J. Biochem. 214, 549-561. doi: 10.1111/j.1432-1033.1993.tb17953.x

Mihara, H., and Esaki, N. (2002). Bacterial cysteine desulfurases: theis function and mechanisms. Appl. Microbiol. Biotechnol. 60, 12-23. doi: 10.1007/s00253-002-1107-4

Milano, T., Contestabile, R., Lo Presti, A., Ciccozzi, M., and Pascarella, S. (2015). The aspartate aminotransferase-like domain of Firmicutes MocR transcriptional retulators. Comput. Biol. Chem. 58, 55-61. doi: 10.1016/j.compbiolchem.2015.05.003

Milano, T., Gulzar, A., Narzi, D., Guidoni, L., and Pascarella, S. (2017). Molecular dynamics simulation unveils the conformational flexibility of the interdomain linker in the bacterial transcriptional regulator GabR from Bacillus subtilis bound to pyridoxal 5'-phosphate. PLoS ONE 12:e0189270. doi: 10.1371/journal.pone.0189270

Milner, J. L., Silo-Suh, L., Lee, J. C., He, H., Clardy, J., and Handelsman, J. (1996). Production of kanosamine by Bacillus cereus UW85. Appl. Environ. Microbiol. 62, 3061-3065.

Mirouze, N., Bidnenko, E., Noirot, P., and Auger, S. (2015). Genome-wide mapping of TnrA-binding sites provides new insights into the TnrA regulon in Bacillus subtilis. Microbiologyopen 4, 423-435. doi: 10.1002/ mbo3.249

Mittenhuber, G. (2001). Phylogenetic analyses and comparative genomics of vitamin B6 (pyridoxine) and pyridoxal phosphate biosynthesis pathways. J. Mol. Microbiol. Biotechnol. 3, 1-20.

Mizote, T., Tsuda, M., Smith, D. D., Nakayama, H., and Nakazawa, T. (1999). Cloning and characterization of the thiD/J gene of Escherichia coli encoding a thiamin-synthesizing bifunctional enzyme, hydroxymethylpyrimidine kinase/phosphomethylpyrimidine kinase. Microbiology 145, 495-501. doi: 10.1099/13500872-145-2-495

Mizushina, Y., Xu, X., Matsubara, K., Murakami, C., Kuriyama, I., Oshige, M., et al. (2003). Pyridoxal $5^{\prime}$-phosphate is a selective inhibitor in vivo of DNA polymerase alpha and epsilon. Biochem. Biophys. Res. Commun. 312, 1025-1032. doi: 10.1016/j.bbrc.2003.11.027

Moccand, C., Boycheva, S., Surriabre, P., Tambasco-Studart, M., Raschke, M., Kaufmann, M., et al. (2014). The pseudoenzyme PDX1.2 boosts vitamin B6 biosynthesis under heat and oxidative stress in Arabidopsis. J. Biol. Chem. 289, 8203-8216. doi: 10.1074/jbc.M113.540526

Molle, V., Fujita, Y., Jensen, S. T., Eichenberger, P., González-Pastor, J. E., Liu, J. S., et al. (2003b). The Spo0A regulon of Bacillus subtilis. Mol. Microbiol. 50, 1683-1701. doi: 10.1046/j.1365-2958.2003. 03818.x

Molle, V., Nakaura, Y., Shivers, R. P., Yamaguchi, H., Losick, R., Fujita, Y., et al. (2003a). Additional targets of the Bacillus subtilis global regulator CodY identified by chromatin immunoprecipitation and genome-wide transcript analysis. J. Bacteriol. 185, 1911-1922. doi: 10.1128/JB.185.6.19111922.2003

Mooney, S., and Hellmann, H. (2010). Vitamin B6: killing two birds with one stone. Phytochemistry 71, 495-501. doi: 10.1016/j.phytochem.2009.12.015
Mooney, S., Leuendorf, J. E., Hendrickson, C., and Hellmann, H. (2009). Vitamin B6: a long known compound of surprising complexity. Molecules 14, 329-351. doi: 10.3390/molecules14010329

Nagahashi, Y., Tazoe, M., and Hoshino, T. (2008). Cloning of the pyridoxine $5^{\prime}$-phosphatase gene (pdxP) and vitamin $\mathrm{B} 6$ production in pdxP recombinant Sinorhizobium meliloti. Biosci. Biotechnol. Biochem. 72, 421-427. doi: 10.1271/bbb.70539

Nakano, S., Nakano, M. M., Zhang, Y., Lellakriangsak, M., and Zuber, P. (2003). A regulatory protein that interferes with activator-stimulated transcription in bacteria. Proc. Natl. Acad. Sci. U.S.A. 100, 4233-4238. doi: $10.1073 /$ pnas. 0637648100

Nester, E. W., and Montoya, A. L. (1976). An enzyme common to histidine and aromatic amino acid biosynthesis in Bacillus subtilis. J. Bacteriol. 126, 699-705.

Newman, J. A., Das, S. K., Sedelnikova, S. E., and Rice, D. W. (2006a). Cloning, purification and preliminary crystallographic analysis of a putative pyridoxal kinase from Bacillus subtilis. Acta Crystallogr. Sect. F Struct. Biol. Cryst. Commun. 62, 1006-1009. doi: 10.1107/S1744309106035779

Newman, J. A., Das, S. K., Sedelnikova, S. E., and Rice, D. W. (2006b). The crystal structure of an ADP complex of Bacillus subtilis pyridoxal kinase provides evidence for the parallel emergence of enzyme activity during evolution. J. Mol. Biol. 363, 520-530. doi: 10.1016/j.jmb.2006.08.013

Nicolas, P., Mäder, U., Dervxn, E., Rochat, T., Leduc, A., Pigeonneau, N., et al. (2012). Condition-dependent transcriptome reveals highlevel regulatory architecture in Bacillus subtilis. Science 335, 1103-1106. doi: $10.1126 /$ science. 1206848

Oberhardt, M. A., Zarecki, R., Reshef, L., Xia, F., Druan-Frigola, M., Schreiber, R., et al. (2016). Systems-wide prediction of enzyme promiscuity reveals a new underground alternative route for pyridoxal $5^{\prime}$-phosphate production in E. coli. PLoS Comput. Biol. 12:e1004705. doi: 10.1371/journal.pcbi.1004705

Ogata, Y., Katoh, H., Asayama, M., and Chohnan, S. (2014). Role of prokaryotic type I and III pantothenate kinases in the coenzyme A biosynthesis pathway. Can. J. Microbiol. 60, 297-305. doi: 10.1139/cjm-2013-0793

Ogura, M., and Kanesaki, Y. (2018). Newly identified nucleoid-associated-like protein YlxR regulates metabolic gene expression in Bacillus subtilis. $m$ Sphere 3, e00501-e00518. doi: 10.1128/mSphere.00501-18

Ohsawa, H., and Gualerzi, C. (1981). Structure-function relationship in Escherichia coli initiation factors. Identification of a lysine residue in the ribosomal binding site of initiation factor by site-specific chemical modification with pyridoxal phosphate. J. Biol. Chem. 256, 4905-4912.

Oka, T., Sugitatsu, H., Nordin, H., Thakur, M. K., Aoyama, M., Sasagawa, T., et al. (2001). Pyridoxal 5'-phosphate inhibits DNA binding of HNF1. Biochim. Biophys. Acta 1568, 189-196. doi: 10.1016/S0304-4165(01)00221-5

Okuda, K., Ito, T., Goto, M., Takenaka, T., Hemmi, H., and Yoshimura, T. (2015b). Domain characterization of Bacillus subtilis GabR, a pyridoxal 5'phosphate-dependent transcriptional regulator. J. Biochem. 158, 225-234. doi: $10.1093 / \mathrm{jb} / \mathrm{mvv} 040$

Okuda, K., Kato, S., Ito, T., Shiraki, S., Kawase, Y., Goto, K., et al. (2015a). Role of the aminotransferase domain in Bacillus subtilis GabR, a pyridoxal 5' phosphate-dependent transcriptional regulator. Mol. Microbiol. 95, 245-257. doi: $10.1111 / \mathrm{mmi} .12861$

Park, J. H., Burns, K., Kinsland, C., and Begley, T. P. (2004). Characterization of two kinases involved in thiamine pyrophosphate and pyridoxal phosphate biosynthesis in Bacillus subtilis: 4-amino-5-hydroxymethyl-2methylpyrimidine kinase and pyridoxal kinase. J. Bacteriol. 186, 1571-1573. doi: 10.1128/JB.186.5.1571-1573.2004

Park, J. H., Johansson, H. E., Aoki, H., Huang, B. X., Kim, H. Y., Ganoza, M. C., et al. (2012). Post-translational modification by $\beta$-lysylation is required for activity of Escherichia coli elongation factor P (EF-P). J. Biol. Chem. 287, 2579-2590. doi: 10.1074/jbc.M111.309633

Park, S. A., Park, Y. S., and Lee, K. S. (2017). Crystal structure of the Cterminal domain of Bacillus subtilis GabR reveals a closed conformation by $\gamma$-aminobutyric acid binding, inducing transcriptional activation. Biochem. Biophys. Res. Commun. 487, 287-291. doi: 10.1016/j.bbrc.2017.04.052

Parra, M., Stahl, S., and Hellmann, H. (2018). Vitamin B6 and its role in cell metabolism and physiology. Cells 7:84. doi: 10.3390/cells7070084

Parsot, C. (1986). Evolution of biosynthetic pathways: a common ancestor for threonine synthase, threonine dehydratase and D-serine dehydratase. $E M B O$ J. 5, 3013-3019. doi: 10.1002/j.1460-2075.1986.tb04600.x 
Pauling, H., and Weimann, B. J. (1996). “Vitamin B6," in Ullmann's Encyclopedia of Industrial Chemistry, Vol. A27, eds H. J. Arpe, E. Biekert, H. T. Davis, W. Gerhartz, H. Gerrens, W. Keim, J. L. McGuire, A. Mitsutani, H. Pilat, C. Reece, H. E. Simmons, E. Weise, R. Wirtz, and H. R. Wüthrich (Weinheim: Wiley-VCH), 530-540.

Percudani, R., and Peracchi, A. (2003). A genomic overview of pyridoxal-phosphate-dependent enzymes. EMBO Rep. 4, 850-854. doi: 10.1038/sj.embor.embor914

Percudani, R., and Peracchi, A. (2009). The B6 database: a tool for the description and classification of vitamin B6-dependent enzymatic activities and of the corresponding protein families. BMC Bioinformatics 10:273. doi: 10.1186/1471-2105-10-273

Perkins, J. B., Bower, S., Howitt, C. L., Yocum, R. R., and Pero, J. (1996). Identification and characterization of transcripts from the biotin biosynthetic operon of Bacillus subtilis. J. Bacteriol. 178, 6361-6365. doi: 10.1128/jb.178.21.6361-6365.1996

Pflug, W., and Lingens, F. (1978). Vitamin B6 biosynthesis in Bacillus subtilis. Hoppe Seylers Z. Physiol. Chem. 359, 559-570. doi: 10.1515/bchm.1978.359.1.559

Phillips, R. S. (2015). Chemistry and diversity of pyridoxal-5'-phosphate dependent enzymes. Biochim. Biophys. Acta 1854, 1167-1174. doi: 10.1016/j.bbapap.2014.12.028

Pierce, K. J., Salifu, S. P., and Tangney, M. (2008). Gene cloning and characterization of a second alanine racemase from Bacillus subtilis encoded by yncD. FEMS Microbiol. Lett. 283, 69-74. doi: 10.1111/j.1574-6968.2008.01151.x

Prunetti, L., El Yacoubi, B., Schiavon, C. R., Kirkpatrick, E., Huang, L., Bailly, M., et al. (2016). Evidence that COG0325 proteins are involved in PLP homeostasis. Microbiology 162, 694-706. doi: 10.1099/mic.0.000255

Pozsgai, E. R., Blair, K. M., and Kearns, D. B. (2012). Modified mariner transposons for random inducible-expression insertions and transcriptional reporter fusion insertions in Bacillus subtilis. Appl. Environ. Microbiol. 78, 778-785. doi: 10.1128/AEM.07098-11

Rajakovich, L. J., Tomlinson, J., and Dos Santos, P. C. (2012). Functional analysis of Bacillus subtilis genes involved in the biosynthesis of 4-thiouridine in tRNA. J. Bacteriol. 194, 4933-4940. doi: 10.1128/JB.00842-12

Ramazzina, I., Costa, R., Cendron, L., Berni, R., Peracchi, A., Zanotti, G., et al. (2010). An aminotransferase branch point connects purine catabolism to amino acid recycling. Nat. Chem. Biol. 6, 801-806. doi: 10.1038/nchembio.445

Raschle, T., Amrhein, N., and Fitzpatrick, T. B. (2005). On the two components of pyridoxal 5'-phosphate synthase from Bacillus subtilis. J. Biol. Chem. 280, 32291-32300. doi: 10.1074/jbc.M501356200

Reitzer, L. (2005). Catabolism of amino acids and related compounds. EcoSal Plus 1, 1-56. doi: 10.1128/ecosalplus.3.4.7

Reuss, D. R., Commichau, F. M., Gundlach, J., Zhu, B., and Stülke, J. (2016). The blueprint of a minimal cell: miniBacillus. Microbiol. Mol. Biol. Rev. 80, 955-987. doi: 10.1128/MMBR.00029-16

Richards, J., Liu, Q., Pellegrini, O., Celesnik, H., Yao, S., Bechhofer, D. H., et al. (2011). An RNA pyrophosphohydrolase triggers $5^{\prime}$ exonucleolytic degradation of mRNA in B. subtilis. Mol. Cell 43, 940-949. doi: 10.1016/j.molcel.201 1.07 .023

Romo, A. J., and Liu, H. W. (2011). Mechanisms and structures of vitamin B6dependent enzymes involved in deoxy sugar biosynthesis. Biochim. Biophys. Acta 1814, 1534-1547. doi: 10.1016/j.bbapap.2011.02.003

Rosenberg, I. H. (2012). A history of the isolation and identification of vitamin B6. Ann. Nutr. Metab. 61, 236-238. doi: 10.1159/000343113

Rosenberg, J., and Commichau, F. M. (2019). Harnessing underground metabolism for pathway development. Trends Biotechnol. 37, 29-37. doi: 10.1016/j.tibtech.2018.08.001

Rosenberg, J., Ischebeck, T., and Commichau, F. M. (2017). Vitamin B6 metabolism in microbes and approaches for fermentative production. Biotechnol. Adv. 35, 31-40. doi: 10.1016/j.biotechadv.2016.11.004

Rosenberg, J., Müller, P., Lentes, S., Thiele, M. J., Zeigler, D. R., Tödter, D., et al. (2016). ThrR, a DNA-binding transcription factor involved in controlling threonine biosynthesis in Bacillus subtilis. Mol. Microbiol. 101, 879-893. doi: $10.1111 / \mathrm{mmi} .13429$

Rosenberg, J., Yeak, K. C., and Commichau, F. M. (2018). A two-step evolutionary process establishes a non-native vitamin B6 pathway in Bacillus subtilis. Environ. Microbiol. 20, 156-168. doi: 10.1111/1462-2920.13950
Rossolillo, P., Marinoni, I., Galli, E., Colosimo, A., and Albertini, A. M. (2005). YrxA is the transcriptional regulator that represses de novo NAD biosynthesis in Bacillus subtilis. J. Bacteriol. 187, 7155-7160. doi: 10.1128/JB.187.20.7155-7160.2005

Rudolph, J., Kim, J., and Copley, S. D. (2010). Multiple turnovers of the nicotinoenzyme PdxB require $\alpha$-keto acids as cosubstrates. Biochemistry 49, 9249-9255. doi: $10.1021 /$ bi101291d

Rueff, A. S., Chastanet, A., Domínguez-Escobar, J., Yao, Z., Yates, J., Prejean, M. V., et al. (2014). An early cytoplasmatic step of peptidoglycan synthesis is associated to MreB in Bacillus subtilis. Mol. Microbiol. 91, 348-362. doi: $10.1111 / \mathrm{mmi} .12467$

Sachla, A. J., and Helmann, J. D. (2019). A bacterial checkpoint protein for ribosome assembly moonlights as an essential metabolite proofreading enzyme. Nat. Commun. 10:1526. doi: 10.1038/s41467-019-09508-z

Sakai, A., Kita, M., Katsuragi, T., Ogasawara, N., and Tani, Y. (2002b). yaaD and yaaE are involved in vitamin B6 biosynthesis in Bacillus subtilis. J. Biosci. Bioeng. 93, 309-312. doi: 10.1263/jbb.93.309

Sakai, A., Kita, M., Katsuragi, T., and Tani, Y. (2002a). serC is involved in vitamin B6 biosynthesis in Escherichia coli but not in Bacillus subtilis. J. Biosci. Bioeng. 93, 334-337. doi: 10.1263/jbb.93.334

Sarge, S., Haase, I., Illarionov, B., Laudert, D., Hohmann, H. P., Bacher, A., et al. (2015). Catalysis of an essential step in vitamin B2 biosynthesis by a consortium of broad spectrum hydrolases. ChemBioChem 16, 2466-2469. doi: $10.1002 /$ cbic. 201500352

Schmidt, A., Sivaraman, J., Li, Y., Larocue, R., Barbosa, J. A., Smith, C., et al. (2001). Three-dimensional structure of 2-amino-3-ketobutyrate CoA ligase from Escherichia coli complexed with a PLP-substrate intermediate: inferred reation mechanism. Biochemistry 40, 5151-5160. doi: 10.1021/bi002204y

Schnackerz, K. D., Tai, C. H., Pötsch, R. K., and Cook, P. F. (1999). Substitution of pyridoxal $5^{\prime}$-phosphate in D-serine dehydratase from Escherichia coli by cofactor analogues provides information on cofactor binding and catalysis. $J$. Biol. Chem. 274, 36935-36943. doi: 10.1074/jbc.274.52.36935

Schultz, A. C., Nygaard, P., and Saxlid, H. H. (2001). Functional anaylsis of 14 genes that constitute the purine catabolic pathway in Bacillus subtilis and evidence for a novel regulon controlled by the PucR transcription activator. J. Bacteriol. 183, 3293-3302. doi: 10.1128/JB.183.11.3293-3302.2001

Schulz, A., Stöveken, N., Binzen, I. M., Hoffmann, T., Heider, J., and Bremer, E. (2017). Feeding on compatible solutes: a substrate-induced pathway for uptake and catabolism of ectoines and its genetic control by EnuR. Environ. Microbiol. 19, 926-946. doi: 10.1111/1462-2920.13414

Sekowska, A., Bertin, P., and Danchin, A. (1998). Characterization of polyamine synthesis pathway in Bacillus subtilis 168. Mol. Microbiol. 29, 851-858. doi: 10.1046/j.1365-2958.1998.00979.x

Sekowska, A., and Danchin, A. (2002). The methionine salvage pathway in Bacillus subtilis. BMC Microbiol. 2:8. doi: 10.1186/1471-2180-2-8

Shimotsu, H., Kuroda, M. I., Yanofsky, C., and Henner, D. J. (1986). Novel form of transcription attenuation regulates expression of the Bacillus subtilis tryptophan operon. J. Bacteriol. 166, 461-471. doi: $10.1128 / \mathrm{jb}$.166.2.461-471.1986

Simon, E. S., and Allison, J. (2009). Determination of pyridoxal-5'-phosphate (PLP)-bonding sites in proteins: a peptide mass fingerprinting approach based on diagnostic tandem mass spectral features of PLP-modified peptides. Rapid Commun. Mass Spectrom. 23, 3401-3408. doi: 10.1002/rcm.4270

Sivaraman, J., Li, Y., Banks, J., Cane, D. E., Matte, A., and Cygler, M. (2003). Crystal structure of Escherichia coli PdxA, an enzyme involved in the pyridoxal phosphate biosynthesis pathway. J. Biol. Chem. 278, 43682-43690. doi: 10.1074/jbc.M306344200

Smirnov, S. V., Sokolov, P. M., Kodera, T., Sugiyama, M., Hibi, M., Shimizu, S., et al. (2012). A novel family of bacterial dioxygenases that catalyse the hydroxylation of free L-amino acids. FEMS Microbiol. Lett. 331, 97-104. doi: 10.1111/j.1574-6968.2012.02558.x

Smith, A. M., Brown, W. C., Harms, E., and Smith, J. L. (2015). Crystal structures capture three states in the catalytic cycle of a pyridoxal phosphate (PLP) synthase. J. Biol. Chem. 290, 5226-5239. doi: 10.1074/jbc.M114. 626382

Sprenger, G. A., Schorken, U., Wiegert, T., Grolle, S., de Graaf, A. A., Taylor, S. V., et al. (1997). Identification of a thiamin-dependent synthase in Escherichia coli required for the formation of the 1-deoxy-D-xylulose 5-phosphate precursor 
to isoprenoids, thiamin, and pyridoxol. Proc. Natl. Acad. Sci. U.S.A. 94, 12857-12862. doi: 10.1073/pnas.94.24.12857

Steil, L., Serrano, M., Henriques, A. O., and Völker, U. (2005). Genomewide analysis of temporally regulated and compartment-specific gene expression in sporulating cells of Bacillus subtilis. Microbiology 151, 399-420. doi: 10.1099/mic.0.27493-0

Stolz, J., and Vielreicher, M. (2003). Tpn1p, the plasma membrane vitamin B6 transporter of Saccharomyces cerevisiae. J. Biol. Chem. 21, 18990-18996. doi: 10.1074/jbc.M300949200

Strohmeier, M., Raschle, T., Mazurkiewicz, J., Rippe, K., Sinning, I., Fitzpatrick, T. B., et al. (2006). Structure of a bacterial pyridoxal $5^{\prime}$-phosphate synthase complex. Proc. Natl. Acad. Sci. U.S.A. 103, 19284-19289. doi: 10.1073/pnas.0604950103

Sugimoto, R., Saito, N., Shimada, T., and Tanaka, K. (2017). Identification of YbhA as the pyridoxal $5^{\prime}$-phosphate (PLP) phosphatase in Escherichia coli: importance of PLP homeostasis on the bacterial growth. J. Gen. Appl. Microbiol. 63, 362-368. doi: 10.2323/jgam.2017.02.008

Sun, D., and Setlow, P. (1993). Cloning, nucleotide sequence, and regulation of the Bacillus subtilis nadB gene and a nifS-like gene, both of which are essential for NAD biosynthesis. J. Bacteriol. 175, 1423-1432. doi: $10.1128 /$ jb.175.5.1423-1432.1993

Suvorova, I. A., and Rodionov, D. A. (2016). Comparative genomics of pyridoxal 5 -phosphate-dependent transcription factor regulons in bacteria. Microb. Genom. 2:e00047. doi: 10.1099/mgen.0.000047

Szydlowski, N., Bürkle, L., Pourcel, L., Moulin, M., Stolz, J., and Fitzpatrick, T. B. (2013). Recycling of pyridoxine (vitamin B6) by PUP1 in Arabidopsis. Plant J. 75, 40-52. doi: 10.1111/tpj.12195

Takiff, H. E., Baker, T., Copeland, T., Chen, S. M., and Court, D. L. (1992). Locating essential Escherichia coli genes by using mini-Tn10 transposons: the pdxJ operon. J. Bacteriol. 174, 1544-1553. doi: 10.1128/jb.174.5.1544-1553.1992

Tanaka, T., Tateno, Y., and Gojobori, T. (2005). Evolution of vitamin B6 (pyridoxine) metabolism by gain and loss of genes. Mol. Biol. Evol. 22, 243-250. doi: 10.1093/molbev/msi011

Tanous, C., Soutourina, O., Raynal, B., Hullo, M. F., Mervelet, P., Gilles, A. M., et al. (2008). The CymR regulator in complex with the enzyme CysK controls cysteine metabolism in Bacillus subtilis. J. Biol. Chem. 283, 35551-35560. doi: 10.1074/jbc.M805951200

Tazoe, M., Ichikawa, K., and Hoshino, Z. (2005). Purification and characterization of pyridoxine $5^{\prime}$-phosphate phosphatase from Sinorhizobium meliloti. Biosci. Biotechnol. Biochem. 69, 2277-2284. doi: 10.1271/bbb.69.2277

Tazoe, M., Ichikawa, K., and Hoshino, Z. (2006). Flavin adenine dinucleotidedependent 4-phospho-D-erythronate dehydrogenase is responsible for the 4-phosphohydroxy-L-threonine pathway in vitamin B6 biosynthesis in Sinorhizobium meliloti. J. Bacteriol. 188, 4635-4645. doi: 10.1128/JB.01999-05

Thiaville, J. J., Flood, J., Yurgel, S., Prunetti, L., Elbadawi-Sidhu, M., Hutinet, G., et al. (2016). Members of a novel kinase family (DUF1537) can recycle toxic intermediates into an essential metabolite. ACS Chem. Biol. 19, 2304-2311. doi: 10.1021/acschembio.6b00279

Tomsic, J., McDaniel, B. A., Grundy, F., and Henkin, T. M. (2008). Natural variability in S-adenosylmethionine (SAM)-dependent riboswitches: S-box elements in Bacillus subtilis exhibit differential sensitivity to SAM in vivo and in vitro. J. Bacteriol. 190, 823-833. doi: 10.1128/JB.01034-07

Tramonti, A., Fiascarelli, A., Milano, T., di Salvo, M. L., Nogués, I., Pascarella, S., et al. (2015). Molecular mechanism of PdxR - a transcriptional activator involved in the regulation of vitamin B6 biosynthesis in the probiotic bacterium Bacillus clausii. FEBS J. 282, 2966-2984. doi: 10.1111/febs.13338

Tramonti, A., Milano, T., Nardella, C., di Salvo, M. L., Pascarella, S., and Contestabile, R. (2017). Salmonalle typhimurium PtsJ is a novel MocR-like transcriptional repressor involved in regulating the vitamin B6 salvage pathway. FEBS J. 284, 466-484. doi: 10.1111/febs.13994

Tramonti, A., Nardella, C., di Salvo, M. L., Pascarella, S., and Contestabile, R. (2018). The MocR-like transcription factors: pyridoxal 5'-phosphatedepdendent regulators of bacterial metabolism. FEBS J. 285, 3925-3944. doi: $10.1111 /$ febs.14599

Tremiño, L., Forcada-Nadal, A., Contreras, A., and Rubio, V. (2017). Studies on cyanobacterial protein PipY shed light on structure, potential functions, and vitamin B6-dependent epilepsy. FEBS Lett. 591, 3431-3442. doi: 10.1002/1873-3468.12841
Urusova, D. V., Isupov, M. N., Antonyuk, S., Kachalova, G. S., Obmolova, G., Vagin, A. A., et al. (2012). Crystal structure of D-serine dehydratase from Escherichia coli. Biochim. Biophys. Acta 1824, 422-432. doi: 10.1016/j.bbapap.2011.10.017

Vanderschuren, H., Boycheva, S., Li, K. T., Szydlowski, N., Gruissem, W., and Fitzpatrick, T. B. (2013). Strategies for vitamin B6 biofortification of plants: a dual role as a micronutrient and a stress protectant. Front. Plant. Sci. 4:143. doi: $10.3389 /$ fpls.2013.00143

Vega, D. E., and Margolin, W. (2017). Suppression of a thermosensitive zipA cell division mutant by altering amino acid metabolism. J. Bacteriol. 200, e00535-e00517. doi: 10.1128/JB.00535-17

Vermeersch, J. J., Christmann-Franck, S., Karabashyan, L. V., Fermandjian, S., Mirambeau, G., and Arsène Der Garabedian, P. (2004). Pyridoxal 5' -phosphate inactivates DNA topoisomerase IB by modifying the lysine general acid. Nucleic Acids Res. 32, 5649-5657. doi: 10.1093/nar/gkh897

Vetter, N. D., Langill, D. M., Anjum, S., Boisvert-Martel, J., Jagdhane, R. C., Omene, E., et al. (2013). A previously unrecognized kanosamine biosynthesis pathway in Bacillus subtilis. J. Am. Chem. Soc. 135, 5970-5973. doi: 10.1021/ja40 10255

Wallner, S., Neuwirth, M., Flicker, K., Tews, I., and Macheroux, P. (2009). Dissection of contributions from invariant amino acids to complex formation and catalysis in the heteromeric pyridoxal 5-phosphate synthase complex from Bacillus subtilis. Biochemistry 48, 1928-1935. doi: 10.1021/bi80 $1887 \mathrm{r}$

White, R. S., and Dempsey, W. B. (1970). Purification and properties of vitamin B6 kinase from Escherichia coli B. Biochemistry 9, 4057-4064. doi: 10.1021/bi00823a005

Whittaker, M. M., Penmatsa, A., and Whittaker, J. W. (2015). The Mtm1p carrier and pyridoxal $5^{\prime}$-cofactor trafficking in yeast mitochondria. Arch. Biochem. Biophys. 568, 64-70. doi: 10.1016/j.abb.2015.01.021

Winkelman, J. T., Bree, A. C., Bate, A. R., Eichenberger, P., Gourse, R. L., and Kearns, D. B. (2013). RemA is a DNA-binding protein that activates biofilm matrix gene expression in Bacillus subtilis. Mol. Microbiol. 88, 984-997. doi: $10.1111 / \mathrm{mmi} .12235$

Witzky, A., Hummels, K. R., Tollerson, R., Rajkovic, A., Jones, L. A., Kearns, D. B., et al. (2018). EF-P posttranslational modification has variable impact on polyproline translation in Bacillus subtilis. MBio 9, e00306-e0318. doi: $10.1128 / \mathrm{mBio} .00306-18$

Wu, R., Sanishvili, R., Belitsky, B. R., Juncosa, J. I., Le, H. V., Lehrer, H. J., et al. (2017). PLP and GABA trigger GabR-mediated transcription regulation in Bacillus subtilis via external aldimine formation. Proc. Natl. Acad. Sci. U.S.A. 114, 3891-3896. doi: 10.1073/pnas.1703019114

Wu, Y., Chen, J., Liu, Z., and Wang, F. (2018). Identification of pyridoxalmodified proteins using mass spectrometry. Rapid Commun. Mass Spectrom. 32, 195-200. doi: 10.1002/rcm.8030

Yanagisawa, T., Sumida, T., Ishii, R., Takemoto, C., and Yokoyama, S. (2010). A paralog of lysyl-tRNA synthetase aminoacylates a conserved lysine residue in translation elongation factor P. Nat. Struct. Mol. Biol. 17, 1136-1143. doi: $10.1038 /$ nsmb. 1889

Yang, Y., Tsui, H. C., Man, T. K., and Winkler, M. E. (1998). Identification and function of the pdxY gene, which encodes a novel pyridoxal kinase involved in the salvage pathway of pyridoxal 5' -phosphate biosynthesis in Escherichia coli K-12. J. Bacteriol. 180, 1814-1821.

Yang, Y., Zhao, G., and Winkler, M. E. (1996). Identification of the pdxK gene that encodes pyridoxine (vitamin B6) kinase in Escherichia coli K-12. FEMS Microbiol. Lett. 141, 89-95. doi: 10.1111/j.1574-6968.1996. tb08368.x

Yoon, B. J. (2009). Hidden markov models and their applications in biological sequence analysis. Curr. Genomics 10, 402-415. doi: 10.2174/138920209789177575

Yoshikane, Y., Yokochi, N., Ohnishi, K., Hayashi, H., and Yagi, T. (2006). Molecular cloning, expression and characterization of pyridoxamine-pyruvate aminotransferase. Biochem. J. 396, 499-507. doi: 10.1042/BJ20060078

Zhang, X., Carter, M. S., Vetting, M. W., Francisco, B. S., Zhao, S., AlObaidi, N. F., et al. (2016). Assigment of function to a domain of unknown function: DUF1537 is a new kinase family in catabolic pathways for acid sugars. Proc. Natl. Acad. Sci. U.S.A. 113, E4261-E4269. doi: 10.1073/pnas. 1605546113 
Zhao, G., Pease, A. J., Bharani, N., and Winkler, M. E. (1995). Biochemical characterization of gapB-encoded erythrose 4-phosphate dehydrogenase of Escherichia coli K-12 and its possible role in pyridoxal 5'-phosphate biosynthesis. J. Bacteriol. 177, 2804-2812. doi: $10.1128 /$ jb.177.10.2804-2812.1995

Zhao, G., and Winkler, M. E. (1995). Kinetic limitation and cellular amount of pyridoxine (pyridoxamine) $5^{\prime}$-phosphate oxidase of Escherichia coli K-12. J. Bacteriol. 177, 883-891. doi: 10.1128/jb.177.4.883-891.1995

Zhao, H., Roistacher, D. M., and Helmann, J. D. (2018). Aspartate deficiency limits peptidoglycan synthesis and sensitizes cells to antibiotics targeting cell wall synthesis in Bacillus subtilis. Mol. Microbiol. 109, 826-844. doi: $10.1111 / \mathrm{mmi} .14078$

Zhu, B., and Stülke, J. (2017). SubtiWiki in 2018: from genes and proteins to functional network annotation of the model organism Bacillus subtilis. Nucleic Acids Res. 46, D743-D748. doi: 10.1093/nar/gkx908
Zhu, J., Burgner, J. W., Harms, E., Belitsky, B. R., and Smith, J. L. (2005). A new arrangement of (beta/alpha) 8 barrels in the synthase subunit of PLP synthase. J. Biol. Chem. 280, 27914-27923. doi: 10.1074/jbc.M503642200

Conflict of Interest Statement: The authors declare that the research was conducted in the absence of any commercial or financial relationships that could be construed as a potential conflict of interest.

Copyright $\odot 2019$ Richts, Rosenberg and Commichau. This is an open-access article distributed under the terms of the Creative Commons Attribution License (CC BY). The use, distribution or reproduction in other forums is permitted, provided the original author(s) and the copyright owner(s) are credited and that the original publication in this journal is cited, in accordance with accepted academic practice. No use, distribution or reproduction is permitted which does not comply with these terms. 